\title{
The causative/applicative syncretism in Mbuun (Bantu B87, DRC): Semantic split or phonemic merger?
}

\author{
KOEN BOSTOEN AND LÉON MUNDEKE
}

\begin{abstract}
In Mbuun (B87), a Bantu language spoken in the Bandundu Province of the Democratic Republic of the Congo, the valency-increasing functions of the causative and the applicative have, to a certain extent, the same formal expression. They are encoded morphologically by a derivational suffix which has an uncharacteristic morphophonological realization. It triggers the gemination of the root-final consonant. In this paper, we examine whether this causative/applicative isomorphism is the result of a semantic split or rather the outcome of a phonemic merger. In the first case, the semantic extension must have happened from applicative to causative rather than the cross-linguistically more common evolution from causative to applicative, since the consonant gemination associated with these forms has its origin in the Proto-Bantu applicative suffix *-Id-. In the case of a phonemic merger, however, this applicative suffix would have become homophonous with an originally distinct suffix having a causative effect as the result of convergent morphophonological change. This morpheme cannot be the Proto-Bantu causative suffix *-ici-, which still has a residual causative use in Mbuun.
\end{abstract}

\section{Introduction $^{1}$}

In Bantu languages, as in most other languages in the world, applicative and causative morphemes are usually clearly distinct. Umbundu (R11), for instance, has a causative suffix -is- (1a) and an applicative suffix -il-, which is subject to

\footnotetext{
1. Research for this paper was conducted at the Linguistics Section of the Royal Museum for Central Africa and was facilitated by a grant from the Belgian Development Cooperation. We wish to thank Denis Creissels, Larry Hyman and Thilo Schadeberg for having read and commented on a first draft of this paper. The usual disclaimers apply.
} 
both vowel and nasal harmony (1b) (Schadeberg 1990: 24-25). Leboale (C44) has a causative suffix -is- (2a) and an applicative suffix with three allomorphic realizations: -Il- $\sim-\mathbf{I}-\sim-\mathbf{i}-(2 \mathrm{~b})$ (Motingea 2005: 84-85). ${ }^{2}$ The respective causative and applicative suffixes of both languages are cognate. The causative suffixes are reflexes of *-ici-, which Bastin (1986) reconstructed to Proto-Bantu (PB) in allomorphic variation with a short causative suffix *-i-, see also Schadeberg (2003: 73). The applicative morpheme is in both cases a reflex of the PB suffix *-Id- (Meeussen 1967: 92; Schadeberg 2003: 74).

(1) a. Umbundu causative suffix

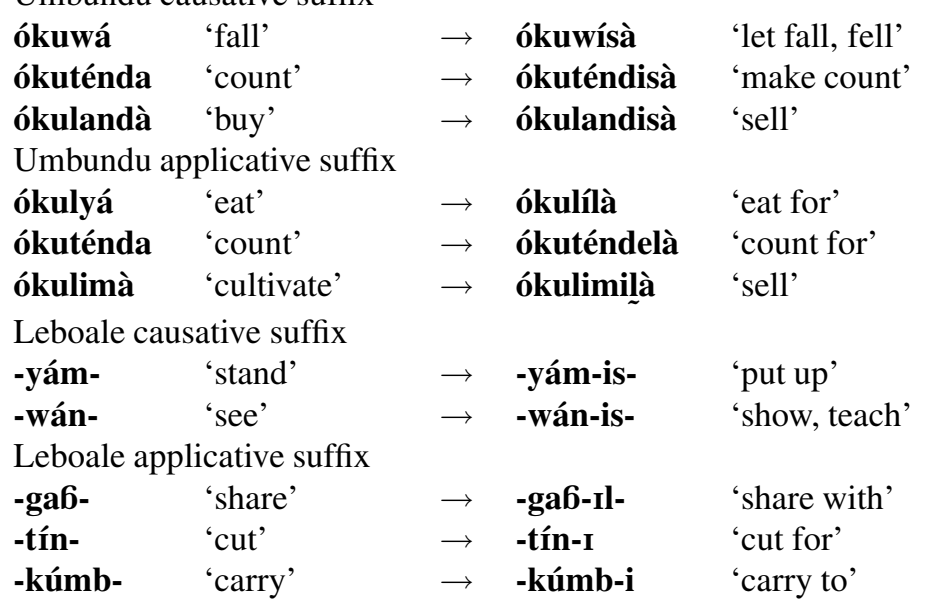

In Mbuun (B87), a Bantu language spoken in the Bandundu Province of the Democratic Republic of the Congo, applicative morphology and causative morphology are to a certain extent identical in form, as suggested by the few examples in (3). ${ }^{3}$

(3) a. Mbuun Applicative

\begin{tabular}{|c|c|c|c|c|}
\hline ka-ból & 'to beat' & $\rightarrow$ & ka-bólle & 'to beat for' \\
\hline ka-kón & 'to plant' & $\rightarrow$ & ka-kónne & 'to plant for' \\
\hline \multicolumn{5}{|c|}{ Mbuun Causative } \\
\hline ka-bel & $\begin{array}{l}\text { 'to boil } \\
\text { (intr.)' }\end{array}$ & $\rightarrow$ & ka-belle & 'to boil (tr.)' \\
\hline ka-kóon & $\begin{array}{l}\text { 'to lose } \\
\text { weight' }\end{array}$ & $\rightarrow$ & ka-kóónne & $\begin{array}{l}\text { 'to make lose } \\
\text { weight' }\end{array}$ \\
\hline
\end{tabular}

2. Bantu languages cited for the first time in this paper will be followed by their Guthrie reference code (Guthrie 1971; Maho 2003).

3. In this paper, we only consider the Mbuun variety spoken in the neighbourhood of Idiofa, which is the mother tongue of the second author. 
In this paper, we examine whether this causative/applicative syncretism is the result of a phonemic merger or whether it is the outcome of a semantic split. In the first case, originally distinct applicative and causative morphemes would have become homophonous as a result of convergent (morpho)phonological change. In the latter case, the causative morpheme would have become associated with applicative functions as is often observed cross-linguistically (Shibatani \& Pardeshi 2002). Or, it may be possible that the applicative morpheme adopted a causative meaning; a semantic shift which is typologically rather rare. In Section 2, we show that the applicative morpheme in Mbuun is a fully productive reflex of PB *-Id-, but with a peculiar morphophonological realization. In Section 3, the canonical uses of the applicative in Mbuun are considered. In Section 4, we examine the residual uses of the PB causative suffix *-ici- in Mbuun, while Section 5 describes those derived verbs, which are similar in shape to true applicatives, but behave semantically and syntactically as causatives. In Section 6, we try to account for the causative/applicative syncretism in Mbuun as the outcome of semantic split. In Section 7, phonemic merger entailing homonymy is considered as a possible historical explanation. In Section 8, we explain how consonant gemination became morphologized as an applicative marker in Mbuun, even in morphologically complex verbs which were originally not applicative. Conclusions are presented in Section 9.

\section{Morphophonological realization of the applicative suffix in Mbuun}

In this section, we argue that applicative morphology in Mbuun has its origin in the Proto-Bantu suffix *-Id-, but that its morphophonological realization is quite uncharacteristic across Bantu. It is relatively easy to describe, but more difficult to analyse.

Mbuun has seven distinctive vowels: i e $\varepsilon$ a $о$ o u. The second degree vowels /e/ and /o/ are often realized as [I] and [ひ] respectively, without phonological contrast with $[\mathbf{e}]$ and $[\mathbf{o}]$ or obvious contextual conditioning. Most Mbuun verb roots have a -CVC- structure with -CV:C- and -CGVC- as subtypes. Unlike many other Bantu languages, the final vowel is generally not realized in Mbuun. Hence, an underived verb stem normally has the same structure as the root, unlike the canonical underived Bantu verb stem, which is - CVC-V. If such a stem is applicativized, no -VC- suffix is added, as is commonly the case in Bantu. The root-final consonant is doubled and followed by /e/, as shown in (4). When the root-final consonant is $/ \mathbf{r} /$, it is turned into $/ \mathbf{t} /$, as in the second example in (4). 


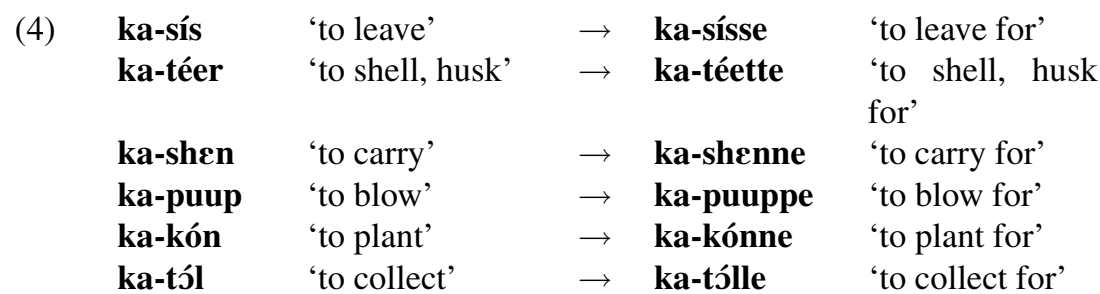

If we assume that these applicative forms are built on the Proto-Bantu morpheme*-Id-, it seems as if this suffix underwent metathesis and its consonant was fully assimilated to the root-final consonant, except when the latter is $/ \mathbf{r} /$ and entails a geminated $/ \mathbf{t} /{ }^{4}$ The geminated nature of the final consonant in applicativized verbs may be difficult to perceive for non-native speakers at normal speech speed. At slow speed, however, it is unmistakable, since an epenthetic vowel /e/ breaks up the consonant cluster, e.g., -kónne $\rightarrow$-kónene, -sísse $\rightarrow$ -sísese, -puuppe $\rightarrow$-puupepe. The final /e/ in Mbuun applicative forms is the regular reflex of the vowel of the reconstructed applicative suffix *-Id-.

When the root vowel is /a/, not only is consonant gemination in applicativized verb forms observed, but also a mutation of the root vowel. As shown in (5), /a/ becomes / $\mathbf{\varepsilon} /$ when it is short and /ee/ when it is long. The variation between a short $/ \boldsymbol{\varepsilon} /$ and a long /ee/ can be considered allophonic, since the prolongation of / $\mathbf{\varepsilon} /$ does not occur in Mbuun (Mundeke 2006: 39).

$\begin{array}{lllll}\text { ka-sal } & \text { 'to weed' } & \rightarrow & \text { ka-sclle } & \text { 'to weed for' } \\ \text { ka-lab } & \text { 'to follow' } & \rightarrow & \text { ka-lebbe } & \text { 'to follow for' } \\ \text { ka-láam } & \text { 'to cook' } & \rightarrow & \text { ka-léemme } & \text { 'to cook for' } \\ \text { ka-baal } & \text { 'to speak' } & \rightarrow & \text { ka-beelle } & \text { 'to speak for' }\end{array}$

The mutation of the root vowel/a/ in these applicative forms can be analysed as an umlaut effect, i.e., the anticipated assimilation of the root vowel to the vowel of the following syllable (cf. Bussmann et al. 1996: 502). This sound shift is also attested diachronically, as shown in (6). It also occurs in other languages of the area, such as Ding (B86) and Yans (B85) (Daeleman 1977; Koni Muluwa \& Bostoen 2011; Rottland 1977).

4. In Mbuun, the consonants $/ \mathbf{t} /$ and $/ \mathbf{r} /$ are in allophonic distribution. The latter only occurs word-finally (Mundeke 2006: 19). Diachronically, /r/ is also the regular reflex of *t in wordfinal position, while /t/ is retained elsewhere, e.g., *tààtá 'father' > táar. 
(6)

\begin{tabular}{|c|c|c|c|}
\hline *-tààdí & 'snake' & $>$ & ntéts \\
\hline *-tádè & 'iron, metal' & $>$ & otél \\
\hline *-pangI & 'sister' & $>$ & ḿpey \\
\hline *-gàdí & 'oil' & $>$ & méets \\
\hline *-kádí & 'wife' & $>$ & ókets \\
\hline *-kápí & 'paddle' & $>$ & nkey \\
\hline
\end{tabular}

Related to this mutation of the /a/ root vowel is the diphthongization of the root vowels /o/ and /o/, which is also observed in closeley related languages (Daeleman 1977; Koni Muluwa \& Bostoen 2011; Rottland 1977). This mutation occurs in certain Mbuun applicative forms, but strangely enough, as shown in (7), only systematically when the verb takes a 1sG object marker.
y-kwénne 'plant for me'
vs. mó-kónne 'plant for him' (<-kón)
m-bwélle 'beat for me'
vs. mó-bólle 'beat for him' (<-ból $)$
n-twélle 'collect for me' vs. mó-tólle 'collect for him' (<-tól)
n-lwébbe 'fish for me' vs. mó-lóbbe 'fish for him' (<-lób)

The 1sG object marker is the only one to take the shape -N-. All others have -(C)V-. It is not clear, however, how this could explain why diphthongization is solely observed in this context. The change of the mid back vowels /o/ and /o/ into a rising diphthong with a final mid front vowel having the same aperture degree is also observed diachronically, when a front vowel follows in the next syllable. This is illustrated by the agent nouns in (8a). The common Bantu agentive suffix *-i triggered the diphthongization of the preceding back vowel before being deleted through word-final vowel loss, which is regular in Mbuun. Underived nouns having a mid back $\mathrm{V}_{1}$ and a front $\mathrm{V}_{2}$, as in $(8 \mathrm{~b})$, underwent the same diachronic sound shift. Hence, the applicative verbs with a 1sG object marker in (7) are most likely retentions. The absence of diphthongization in the applicative of verb roots with a mid back vowel would then be an innovation. This is corroborated by the fact that diphthongization is still sporadically observed in applicative verbs which do not have a 1sG object marker; see for instance the verb form wákwebbe in example (50d), which is derived from the verb -koba 'put on weight, fatten', listed in (40). In any case, it is not clear why the archaic form was only preserved in the presence of a 1sG object marker.

$$
\begin{array}{lllll}
\text { a. ka-kón 'plant' } & \text { vs. o-kwén } & \text { 'cultivator' } & (<* \text {-kún-i) } \\
\text { ka-bór 'give birth' } & \text { vs. o-bwér } & \text { 'parent' } & (<* \text {-bút-i }) \\
\text { ka-lots 'bewitch' } & \text { vs. o-lwets/ o-lots 'witch' } & (<* \text {-dòg-i }) \\
\text { ka-loy 'teach' } & \text { vs. o-lwey } & \text { 'teacher' } & (<* \text {-dòng-i) }
\end{array}
$$




$\begin{array}{llll}\text { b. *-mòtí } & \text { 'one' } & > & \text {-mwes } \\ \text { *-jókì } & \text { 'honey' } & > & \text { mbwets }^{5}\end{array}$

Root vowel mutations in derived applicative verbs, as illustrated in (5) and (7), are reminiscent of a common Bantu phenomenon known as 'imbrication' (Bastin 1983). It is a process whereby certain verbal suffixes merge or whereby a suffix gets infixed into certain verb roots. It results in a morpheme fusion characterized by the loss of the consonant of the infixed morpheme and the insertion of its vowel in front of the preceding consonant leading to vowel contact. The process can be summarized as follows: $V_{1} C_{1} V_{2} C_{2} V_{3} \rightarrow V_{1} V_{2} C_{1} V_{3}$. In Bantu, imbrication is most often observed with the perfect and/or past tense suffix *-ide, but it also occurs with applicative suffix *-Id- and causative suffix *-ici- in certain languages. ${ }^{6}$ The contraction of $\mathrm{V}_{1}$ and infixed $\mathrm{V}_{2}$ generally produces an output similar to those in (5) or (7). In spite of these resemblances and in contrast to an earlier analysis (Mundeke 2006: 53), we believe that imbrication does not convincingly account for the phenomena described above. Firstly, imbrication most often involves the fusion of one of the above suffixes with a preceding suffix, either a derivational suffix or an unproductive root extension. The infixation of a suffix into the CVC root itself is only observed with a very limited set of verbs, such as *-bón- -món- 'see'. In Mbuun, however, all verb roots fulfilling the right conditions undergo the sound changes described above when they are applicativized. Moreover, imbrication habitually results in long vowels. In the case of Mbuun applicatives, this is not the case. Vowel length is never created, only maintained. Moreover, applicativization in Mbuun systematically involves consonant gemination. This is never observed with imbrication, which always involves the deletion of $\mathrm{C}_{2}{ }^{7}$ Finally, imbrication does not account for the final vowel observed in Mbuun applicatives,

5. This Mbuun noun is not a direct reflex of the reconstruction *-jókì. The noun class prefix *bo- merged with the original noun stem and the new noun stem was reintegrated into class 9, marked by a nasal noun prefix.

6. Mbuun has a perfective suffix -ii, which could be a reflex of *-ide, but which never triggers imbrication (Mundeke 2006: 159).

7. Imbrication accounts better for the morphophonological behaviour of the applicative suffix when it is added to a root with final coronal consonant in the nearby Bantu language Tiene (B81). Where the $\mathrm{C}_{2}$ of the root is coronal, the /l/ of the applicative suffix is lost, its only reflex being the lengthening of the root vowel, e.g., -bót-a 'give birth' $\rightarrow$ bóot- $\varepsilon$ 'give birth for', -yal-a 'spread' $\rightarrow$-yaal-a 'spread for'. However, the behaviour of the applicative suffix when it is added to a root with non-coronal $\mathrm{C}_{2}$ cannot be accounted for as imbrication. In that case, the /// of the applicative is infixed into the root leading to a metathesis with the $\mathrm{C}_{2}$ of the root, e.g., -yob-o 'bathe' $\rightarrow$-yolob-o 'bathe for', -bák-a 'reach' $\rightarrow$-bálak-a 'reach for' (Ellington 1977; Hyman 2010; Hyman \& Inkelas 1997). This phenomenon could be related to the facts observed in Mbuun, but a deeper analysis of the resemblances observed in the morphophonological behaviour of derivational suffixes in both languages goes beyond the scope of this paper. 
though it could be analysed as a default vowel necessary to facilitate the realization of the preceding geminated consonant.

Suffix metathesis, i.e., a -CV-realization of the Proto-Bantu applicative suffix *-Id-, does account for the final vowel in Mbuun applicatives. However, it does not explain the occurrence of consonant gemination in applicativized verbs having a root ending in a vowel: -CV-, -CV:- or -CGV-, as in (9).

$$
\begin{aligned}
& \text { a. ka-bóo 'to break' } \rightarrow \text { ka-bwíille 'to break (*-búd-) } \\
& \text { for' } \\
& \text { ka-bwa 'to fall' } \rightarrow \text { ka-bwéelle 'to fall for' (*-bù-) } \\
& \text { ka-tsii 'to come' } \rightarrow \text { ka-tsiille 'to come (*-jìj-) } \\
& \text { for' } \\
& \text { ka-byée 'to deteri- } \rightarrow \text { ka-byéelle 'to (*-bíìp-) } \\
& \text { orate' deteriorate } \\
& \text { for' } \\
& \text { ka-dzuu 'to kill' } \rightarrow \text { ka-dzwille 'to kill for' } \\
& \text { ka-ta 'to adjust' } \rightarrow \text { ka--tyelle 'to adjust } \\
& \text { for' } \\
& \text { b. ka-kwe 'to go' } \rightarrow \text { ka-kwenne 'to go for' (<*-gènd-?) } \\
& \text { ka-shee 'to laugh' } \rightarrow \text { ka-sheyye 'to laugh (<*-cèk-) } \\
& \text { ka-tée 'to draw } \rightarrow \text { ka-téyye 'to draw (<*-ték-) } \\
& \text { (water)' (water) for' }
\end{aligned}
$$

As can be seen in (9a), the geminated consonant in these cases is most often /l/, but other consonants may turn up as well, as in (9b). The origin of these consonants is not clear, since the base verbs synchronically end in a vowel. In the first example in (9a), where the base verb is a reflex of the proto-form between parentheses, it might be the original root-final consonant $* \mathbf{d}$, which re-emerges or, more exactly, was retained, since $/ \mathbf{l} /$ is a regular reflex of $* \mathbf{d}$. This might also be the case for the first verb in (9b), where the geminated consonant in the applicative form is /n/ and not ///, if at least -kwe is indeed a reflex of *-gènd-. However, for the last two verbs in $(9 b)$, also having a geminated consonant other than $\mathbf{l} /$, this assumption is less plausible, although it should be noted that both are reflexes of a root ending in $/ \mathbf{k} /$. For all other examples in (9), this explanation definitely fails, because $/ \mathbf{l}$ / is not a reflex of the reconstructed root-final consonant or because no root-final consonant was reconstructed at all. Hence, consonant gemination seems to have become generalized as a marker of applicative morphology. It can by no means be morphophonologically accounted for in the case of -CV- verbs. These verbs simply adopted geminated consonants in analogy with -CVC- verbs. Some exceptions notwithstanding, /// seems to have become the default consonant for gemination, if no root-final consonant is synchronically available. This is no coincidence if one 
reckons that $/ \mathbf{l} /$ is the regular reflex of the final consonant of the applicative suffix *-Id-. The geminated /// observed in most forms in (9) might be the result of two successive applicative morphemes. The first fuses with the root, while the second triggers gemination through metathesis. Synchronic evidence for this assumption is provided by the loss of consonant gemination when the reciprocal/associative suffix -in- is affixed to applicativized -CV- roots, as shown in (10). This suffix is the only one which can be productively added to another suffix in Mbuun. Besides the applicative, it is only observed in combination with the causative suffix -is-, always as last element. It triggers nasal assimilation of the preceding lateral approximant, if the latter belongs to the applicative suffix.

\begin{tabular}{|c|c|c|}
\hline Base verb & Applicative & Applicative-reciprocal \\
\hline ka-bwa & ka-bwéelle & ka-bwéenin \\
\hline 'to fall' & 'to fall for' & 'to fall for each other' \\
\hline ka-bóo & ka-bwíille & ka-bwínin \\
\hline 'to break' & 'to break for' & 'to break for each other' \\
\hline ka-tsii & ka-tsiille, & ka-tsiinin \\
\hline
\end{tabular}

If the reciprocal/associative suffix is added to an applicativized -CVC- root, however, consonant gemination is maintained as in (11). If the reciprocal/ associative suffix is not preceded by a geminated consonant, the verb is simply reciprocal in meaning. As can be observed in the first example below, nasal assimilation does not affect preceding lateral approximants belonging to the root.

\begin{tabular}{|c|c|c|}
\hline Base verb & Applicative-reciprocal & Reciprocal \\
\hline ka-ból & ka-bóllin & ka-bólin \\
\hline 'to beat' & 'to beat e.o. for' & 'to beat each other' \\
\hline ka-sís & ka-síssin & ka-sísin \\
\hline 'to leave' & 'to leave e.o. for' & 'to leave each other' \\
\hline ka-lab & ka-lebbin & ka-lébin \\
\hline 'to follow' & 'to follow e.o. for' & 'to follow each other' \\
\hline
\end{tabular}

In other words, the applicative suffix in Mbuun only takes its original -VCform when it combines with -CV- roots. If it is not followed by the reciprocal suffix -in, a default applicative suffix is added, which acts as if it follows a -CVC- root, resulting in the characteristic morphophonological output of canonical applicatives in Mbuun, i.e., a geminated consonant.

The functional motivation for this peculiar morphophonological realization of the applicative suffix is not straightforward, but it no doubt ties in with the existence of maximality constraints on the verb stem. It is well-known that 
many north-western Bantu languages put an upper limit on the number of syllables which a verb stem may contain and strictly constrain the stacking of derivational suffixes, unlike the eastern and southern Bantu languages where verb root extensions can pile up more freely (Hyman 2004). In Mbuun, where the final vowel is normally not realized, either in verbs or in nouns, the maximum number of verb stem syllables seems to be only two, in contrast to Tiene (B81), for instance, where it is three (Hyman 2010). Longer verb stems have not been observed. This low upper limit probably explains why many verbal derivational suffixes, amongst other the causative suffix -is-, have lost their productivity (cf. Section 4), and why suffix stacking has become so rare. One would even expect suffix stacking to be impossible, except maybe in combination with -CV- roots. The fact that the applicative suffix has remained fully productive and still allows for adding the reciprocal/associative suffix -in can be attributed to its uncharacteristic morphophonological realization. Because it takes the shape $-\mathrm{CV}$ - instead of - VC-, it can be combined with a second derivational suffix without the verbal stem becoming more than disyllabic. To be sure, this is rather a consequence of its atypical realization than the cause.

\section{Canonical use of the applicative in Mbuun}

Although the morphophonological realization of the applicative is peculiar in Mbuun, its function corresponds to a large extent to the common uses of the reflexes of the suffix *-Id- in Bantu. It allows a thematically peripheral argument or adjunct to be coded as a core object argument of the verb (Peterson 2007: 1). The beneficiary adjunct maám is introduced in (12a) by the preposition óngírá meaning 'for, in favour of, because of, due to', but becomes a core object of the derived applicative verb in $(12 \mathrm{~b}) .^{8}$

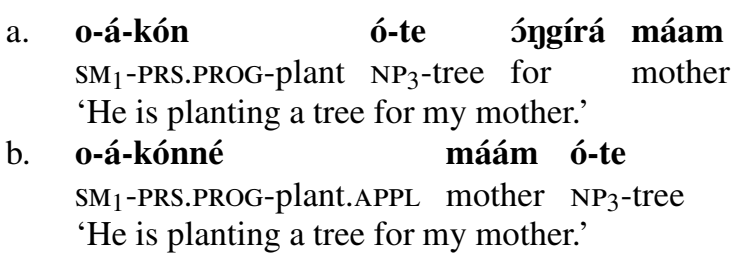

Semantically, the applied object prototypically has the thematic role of beneficiary as in (12b). Instrumental and locative applicative constructions do not exist in Mbuun, as shown in (13a) vs. (13b) and (14a) vs. (14b). However, in

\footnotetext{
8. Etymologically, ó y-gir á (LOM NP9-body CONN) is a prepositional phrase literally meaning 'on the body of'
} 
the context of locative inversion, as in (14c), applicative morphology can be observed, but it is optional (14d) and always allows the insertion of a beneficiary object without further morphological change (14e).
a. o-á-ból
mó-an le o-kul
$\mathrm{SM}_{1}$-PRS.PROG-beat $\mathrm{NP}_{1}$-child with $\mathrm{NP}_{3}$-stone
'He is hitting the child with a stone.'
b. **o-á-bólle mó-an le o-kul
$\mathrm{SM}_{1}$-PRS.PROG-beat.APPL $\mathrm{NP}_{1}$-child with $\mathrm{NP}_{3}$-stone
'He is hitting the child with a stone.'
a. taar o-á-láám m-bíts o m-bvun
father $\mathrm{SM}_{1}$-PRS.PROG-cook NP9-meat LOC NP9-field
'My father is preparing meat in the field.'
b. **taar o-á-léémmé m-bíts o m-bvun
father $\mathrm{SM}_{1}$-PRS.PROG-Cook.APPL $\mathrm{NP}_{9}$-meat $\quad$ LOC $\quad \mathrm{NP}_{9}$-field
'My father is preparing meat in the field.'
c. J m-bvun mo-á-léémmé táár m-bíts
LOC $\mathrm{NP}_{9}$-field $\mathrm{SM}_{18}$-PRS.PROG-cook.APPL father $\mathrm{NP}_{9}$-meat
'In the field, my father is preparing meat.'
d. o m-bvun mo-á-láám táár m-bíts
LOC $\mathrm{NP}_{9}$-field $\mathrm{SM}_{18}$-PRS.PROG-cook father $\mathrm{NP}_{9}$-meat
'In the field, my father is preparing meat.'
e. o m-bvun mo-á-léémme táár bá-án
LOC $\mathrm{NP}_{9}$-field $\mathrm{SM}_{18}$-PRS.PROG-cook.APPL father $\mathrm{NP}_{2}$-child
m-bíts
NP9-meat
'In the field, my father is preparing meat for the children.'

Thematic roles closely related to the canonical beneficiary meaning of the applied object in Bantu are also attested in Mbuun: recipient as in (15b), maleficiary as in (16b) and reason as in (17b) and (18b) (cf. Cann \& Mabugu 2007; Trithart 1983). Applied objects with purpose meanings as in (19b) seem to be unacceptable.
a. mo-án ó-á-tóm ó-ykaan
$\mathrm{NP}_{1}$-child $\mathrm{SM}_{1}$-PRS.PROG-send $\mathrm{NP}_{3}$-letter
'The child sends a letter.'
b. mo-án ó-á-tómmé táár ó-gkaan
$\mathrm{NP}_{1}$-child $\mathrm{SM}_{1}$-PRS.PROG-send.APPL father $\mathrm{NP}_{3}$-letter
'The child sends a letter to my father.'

a. mo-án ó-á-shee

$\mathrm{NP}_{1}$-child $\mathrm{SM}_{1}$-PRS.PROG-laugh

'The child laughs.' 
b. mo-án ó-á-shéyyé táar

$\mathrm{NP}_{1}$-child $\mathrm{SM}_{1}$-PRS.PROG-laugh.APPL father

'The child makes fun of my father.'

a. mo-án ó-á-byee

$\mathrm{NP}_{1}$-child $\mathrm{SM}_{1}$-PRS.PROG-become.bad

'The child becomes bad.'

$\mathrm{NP}_{1}$-child $\mathrm{SM}_{1}$-PRS.PROG-become_bad.APPL his.mother 'The child becomes bad due to his mother.'
a. n-cús
ó-á-bol

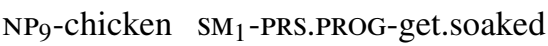

'The chicken gets soaked.'

b. n-cús ó-á-bóllé m-vúl

$\mathrm{NP}_{9}$-chicken $\mathrm{SM}_{1}$-PRS.PROG-get.soaked.APPL NP9-rain

'The chicken gets soaked due to the rain.'

c. n-cús ó-á-ból óngírá / le

$\mathrm{NP}_{9}$-chicken $\mathrm{SM}_{1}$-PRS.PROG-get.soaked due.to / with

m-vul

$\mathrm{NP}_{9}$-rain

'The chicken gets soaked due to the rain.'

(19)
a. mo-íb ó-á-dzúú
óngira n-dzim
$\mathrm{NP}_{1}$-thief $\mathrm{SM}_{1}$-PRS.PROG-kill for $\mathrm{NP}_{9}$-money
'The thief kills for money.'
b. **mo-íb ó-á-dzwíllé n-dzím
$\mathrm{NP}_{1}$-thief $\mathrm{SM}_{1}$-PRS.PROG-kill.APPL $\mathrm{NP}_{9}$-money
'The thief kills for money.'

Syntactically, the applicative suffix canonically increases the verb's valency with one argument: an intransitive verb becomes transitive, as in (20a) vs. (20b), a transitive ditransitive, as in (21a) vs. (21d), and a ditransitive tritransitive, as in (22a) vs. (22b). The object licensed by the applicative suffix is immediately post-verbal and precedes the demoted object(s) of (di)transitive underived verbs.

\section{a. maam o-á-lel}

mother SM $_{1}$-PRS.PROG-weep.APPL

'My mother weeps.'
b. maam o-á-léllé mó-an
mother SM $_{1}$-PRS.PROG-weep.APPL $\mathrm{NP}_{1}$-child
'My mother weeps for the child.'
a. maam o-á-súm é-pis
mother $\mathrm{SM}_{1}$-PRS.PROG-buy $\mathrm{NP}_{8}$-cloth
'My mother buys cloths.'


b.
maam o-á-súmmé
bá-án
é-pis
mother $\mathrm{SM}_{1}$-PRS.PROG-buy.APPL $\mathrm{NP}_{2}$-child $\mathrm{NP}_{8}$-cloth
'My mother buys cloths for the children.'
a. maam o-á-pa
táár ma-c
mother $\mathrm{SM}_{1}$-PRS.PROG-give father $\mathrm{NP}_{6}$-water
'My mother gives my father water.'
b. maam o-á-pyéllé mó-án táár ma-c
mother SM $_{1}$-PRS.PROG-give.APPL $\mathrm{NP}_{1}$-child father $\mathrm{NP}_{6}$-water 'My mother gives my father water for the child.'

Objects of transitive base verbs do not entirely lose their object properties in applicative constructions. ${ }^{9}$ Object markers may substitute both the first (beneficiary) and second (patient) object in the verb. If both objects belong to the same noun class (23a), there is some degree of ambiguity, as in (23b) and (23c). When both objects belong to different noun classes, as in (24), no ambiguity is possible. The object marker referring to the beneficiary is always immediately to the left of the verb root. However, certain applicative verbs, such as -picce in (25), do not allow double object marking when one or both have an inanimate referent, while others, such as -konne in (26), do allow it. Applicative constructions manifest the same objecthood properties as inherently ditransitive verbs, such as -pa in (27).

$$
\text { máám (B) mó-an (P) }
$$

father $\mathrm{SM}_{1}$-PRS.PROG-beat.APPL mother $\mathrm{NP}_{1}$-child

'Father beats the child for mother.'

\section{b. taar o-á-mó-bóllé máam}

father $\mathrm{SM}_{1}$-PRS.PROG-OM 1 -beat.APPL mother
i. 'Father beats it for mother.'
ii. 'Father beats mother for it.'

c. taar o-á-mó-mó-bolle

father SM $_{1}$-PRS.PROG-OM $1-\mathrm{OM}_{1}$-beat.APPL

i. 'Father beats it for her.' ii. 'Father beats her for it.'
a. taar o-á-bóllé
máám (B) bá-an (P)
father $\mathrm{SM}_{1}$-PRS.PROG-beat.APPL mother $\mathrm{NP}_{2}$-child
'Father beats the children for mother.'

b. taar o-á-bá-mó-bolle

father $\mathrm{SM}_{1}$-PRS.PROG-OM $2-\mathrm{OM}_{1}$-beat.APPL

'Father beats them on behalf of her.'

\footnotetext{
9. Nevertheless, the objecthood of patient objects of transitive verbs is to a certain extent reduced in applicative constructions. Animate patient objects cannot be passivized, for instance, but inanimate patient objects can.
} 
a. taar o-á-píccé

máám (B) ki-te (P)

father SM $_{1}$-PRS.PROG-throw_away.APPL mother $\mathrm{NP}_{7}$-chair 'Father throws the chair away for mother.'

b. taar o-á-mó-picce

ki-te

father SM SM $_{1}$-PRS.PROG-OM 1 -throw_away.APPL NP7-chair

'Father throws the chair away for her.'

c. taar o-á-ké-picce máam

father SM $_{1}$-PRS.PROG-OM7-throw_away.APPL mother 'Father throws it away for mother.'

d. **taar o-á-ké-mó-picce

father $\mathrm{SM}_{1}$-PRS.PROG-OM7-OM 1 -throw_away.APPL

'Father throws it away for her.'

\section{ó-á-ké-mó-konne}

$\mathrm{SM}_{1}$-PRS.PROG-OM7-OM 1 -plant.APPL

'He plants it for her.'
a. maam o-á-pá ó-sám (R) i-koon (P)
'Mother gives her friend a banana.'
mother $\mathrm{SM}_{1}$-PRS.PROG-give $\mathrm{NP}_{1}$-friend $\mathrm{NP}_{5}$-banana
b. maam o-á-mó-pa
'Mother gives her a banana.'
i-koon
mother $\mathrm{SM}_{1}$-PRS.PROG-OM $\mathrm{OM}_{1}$-give $\mathrm{NP}_{5}$-banana
c. maam o-á-lá-pá ó-sám
mother $\mathrm{SM}_{1}$-PRS.PROG-OM 5 -give $\mathrm{NP}_{1}$-friend
'Mother gives it to her friend.'
d. maam o-á-lá-mó-pa
mother SM $_{1}$-PRS.PROG-OM5-OM - -give
'Mother gives it to her.'

In some Bantu languages, certain transitive verbs allow the object to be deleted from surface syntax, but do not allow it in (beneficiary) applicative constructions (Simango 1995: 48). In Mbuun, as shown in (28), both patient and beneficiary objects can be omitted from applicative constructions. When the beneficiary object of an applicative verb remains unexpressed, as in (28d), the involvement of the beneficiary is implicit.
a. maam o-á-láám
á-say $\quad$ o $\quad$ n-zuy

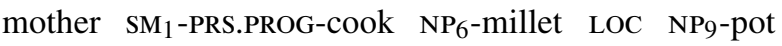 'Mother prepares millet in a cooking pot.'
b. maam o-á-láám $\quad$ o n-zuy
mother SM $_{1}$-PRS.PROG-cook LOC NP9-pot 'Mother cooks in a cooking pot.'




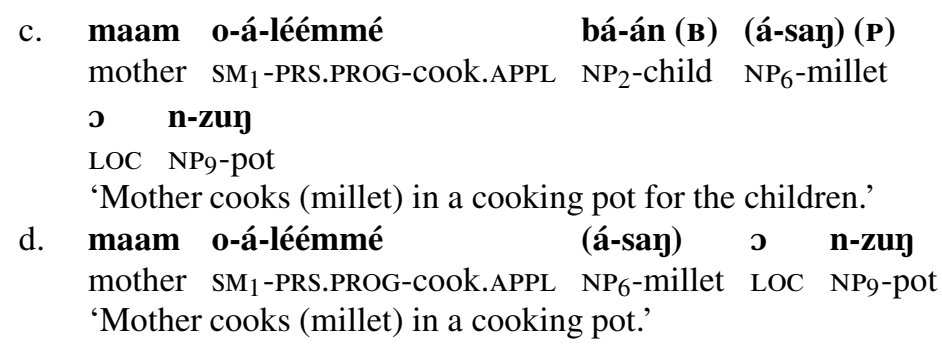

Certain verbs, such as -tem 'call' in (29), do not allow a beneficiary applicative construction. The thematic role of beneficiary is then obligatorily introduced as an oblique argument of the base verb. The acceptance of a beneficiary participant as a core object seems to hinge on the lexical event structure of the verb. Other verbs, such as -ley 'search' in (30), do allow the same participant to be introduced as a core object of the applicative construction.

$$
\begin{aligned}
& \text { a. maam o-á-tém ó-ggáy (P) óngírá m-bwa (B) } \\
& \text { mother } \mathrm{SM}_{1} \text {-PRS.PROG-call } \mathrm{NP}_{1} \text {-doctor for } \quad \mathrm{NP}_{9} \text {-dog } \\
& \text { 'Mother calls the doctor for the dog.' } \\
& \text { b. **maam o-á-témmé } \quad \text { m-bwá (B) o-ygay (P) } \\
& \text { mother } \mathrm{SM}_{1} \text {-PRS.PROG-call.APPL } \mathrm{NP}_{9} \text {-dog } \quad \mathrm{NP}_{1} \text {-doctor } \\
& \text { 'Mother calls the doctor for the dog.' } \\
& \text { maam o-á-léygé mbwá (B) J-ggay (P) } \\
& \text { mother } \text { SM }_{1} \text {-PRS.PROG-seek.APPL NP9-dog } \text { NP }_{1} \text {-doctor } \\
& \text { 'Mother seeks a doctor for (the benefit of) the dog.' }
\end{aligned}
$$

The applicative construction and the prepositional phrase introduced by óngírá are alternative strategies to represent the beneficiary participant or closely related participants in the clause. However, their combination within a clause as in (31) is not ungrammatical. It has the discursive function of putting focus on the oblique (beneficiary/reason) argument.

$$
\begin{aligned}
& \text { a. ó-á-kónné á-say o mbvun óngírá } \\
& \mathrm{SM}_{1} \text {-PRS.PROG-plant.APPL } \mathrm{NP}_{6} \text {-millet } \mathrm{LOC} \quad \mathrm{NP}_{9} \text {-field for } \\
& \text { máam } \\
& \text { mother } \\
& \text { 'He plants the millet on the field FOR MOTHER.' } \\
& \text { b. mo-íb ó-á-dzúú máám óggírá nke? } \\
& \mathrm{NP}_{1} \text {-thief } \mathrm{SM}_{1} \text {-PRS.PROG-kill mother for what } \\
& \text { 'Why does the thief kill mother?' } \\
& \begin{array}{l}
\text { ó-á-mó-dzwíllé } \\
\mathrm{SM}_{1} \text {-PRS.PROG-OM } 1 \text {-kill.APPL for }
\end{array}
\end{aligned}
$$




$$
\begin{aligned}
& \text { c. mo-íb ó-á-dzwíllé máám óngírá nke? } \\
& \mathrm{NP}_{1} \text {-thief } \mathrm{SM}_{1} \text {-PRS.PROG-kill.APPL mother for what } \\
& \text { 'WHY does the thief kill mother?' }
\end{aligned}
$$

In sum, the function of the applicative in Mbuun is in line with the canonical uses of this construction in Bantu. It allows for the introduction of a beneficiary or semantically closely related participant, such as recipient, maleficiary and reason, as a core object argument of the verb. Accordingly, applicative morphology is valency increasing, the applied object always being immediately post-verbal and followed by objects fulfilling other thematic roles, most typically patient.

\section{Residual uses of the Proto-Bantu causative suffix *-ici- in Mbuun}

The reflex of the Proto-Bantu long causative suffix *-ici- still exists in Mbuun, but its use is no longer productive. Its basic form -is- is only observed with $-\mathrm{C}(\mathrm{G}) \mathrm{V}(\mathrm{V})$ - roots as in (32), even though it is not always realized as -is-, as the last example illustrates.

$$
\begin{aligned}
& \text { ká-dya 'to eat' } \rightarrow \text { ká-díis 'to feed' } \\
& \text { ká-nwa 'to drink' } \rightarrow \text { ká-nwíis 'to give to drink' } \quad \text { (*-dí-) } \\
& \text { ká-bwa 'to fall' } \rightarrow \text { ká-bwíis 'to drop (= cause to fall)' }{ }^{*} \text {-bò-) } \\
& \text { ka-túu 'to leave' } \rightarrow \text { ka-túus 'to put out, throw out, ex- } \\
& \quad \text { pel'10 }
\end{aligned}
$$

Semantically, the causative suffix -is- prototypically expresses direct causation. The subject (causer) of the derived causative verb is agentive and (physically) manipulates the object (causee), which does not act as a volitional entity and is thus patientive, even if a human being is involved (cf. Shibatani \& Pardeshi 2002: 89). Indirect causation involving two agentive participants is expressed by means of periphrastic constructions in Mbuun. Indirect causatives rely on auxiliaries, such as -shína 'send', and need more detailed study.

Syntactically, the causative suffix is valency-increasing: intransitive verbs become transitive, as in (33a) vs. (33b), and transitive verbs become ditransitive, as in (34a) vs. (34b). The derived causative verb generally introduces a new subject with the semantic role of causer, while the agent-subject of the underived verb becomes an object of the derived causative verb with the semantic role of causee (Dixon 2000: 30-31). In the case of a ditransitive causative verb,

10. As an anonymous reviewer pointed out, the deviant form of -túus might be explained by the fact that it contains the Proto-Bantu short causative suffix *-i-. The base verb -túu could be a reflex of *-túvk- 'come from' (Bastin et al. 2002). However, neither its meaning nor its vowel heightcorrespond exactly. 
as in (33d), the causee object (C) is always immediately post-verbal and precedes the patient object $(\mathrm{P})$.
a. mo-án ó-á-túu
$\mathrm{NP}_{1}$-child $\mathrm{SM}_{1}$-PRS.PROG-leave
'The child is leaving.'
b. maam o-á-túús mó-an (C)
mother $\mathrm{SM}_{1}$-PRS.PROG-leave.CAUS $\mathrm{NP}_{1}$-child
'My mother is throwing the child out.'
a. mo-án ó-á-dya buu (P)
$\mathrm{NP}_{1}$-child $\mathrm{SM}_{1}$-PRS.PROG-eat fufu
'The child is eating fufu.'
b. maam o-á-díís mó-án (c) buu (P)
mother $\mathrm{SM}_{1}$-PRS.PROG-eat.CAUS $\mathrm{NP}_{1}$-child fufu
'My mother is feeding the child with fufu.'

These derived causative forms of -CV- roots can in their turn be applicativized. As shown in (35), these causative-applicative verbs manifest a gemination of the causative suffix consonant as opposed to the simple applicative forms where the default geminated /// surfaces. This indicates that the morpheme order is causative-applicative.

\begin{tabular}{|c|c|c|c|c|}
\hline \multicolumn{3}{|l|}{ Causative } & \multicolumn{2}{|c|}{ Causative-applicative } \\
\hline ká-díis & 'feed' & $\rightarrow$ & ká-díisse & vs. \\
\hline ká-nwíis & 'give to drink' & $\rightarrow$ & ká-nwíisse & vs. \\
\hline ká-bwíis & ‘drop’ & $\rightarrow$ & ká-bwíisse & vs. \\
\hline
\end{tabular}

Syntactically, such applicativized causative verbs can take one more object. Verbs that are intransitive in their underived state then take three arguments as in (36a), while originally transitive verbs take then four arguments as in (36b). The beneficiary object (B) is always immediately post-verbal and precedes the causee object (C), which precedes in its turn the patient object (P).
a. taar o-á-bwííssé
máám (в) n-dzo (C)
father $\mathrm{SM}_{1}$-PRS.PROG-fall.cAus mother $\mathrm{NP}_{9}$-house
'Father is making the house fall down for mother.'
b. maam o-á-dí́ssé táár (B) mó-án (C) buu (P) mother $\mathrm{SM}_{1}$-PRS.PROG-eat.CAUs father $\mathrm{NP}_{1}$-child fufu 'Mother is feeding the child with fufu for father.'

Roots with a-CVC- structure generally do not allow productive causative morphology. Nevertheless, Mbuun has several lexicalized causative verbs, as in (37), which are morphologically similar to the causative-applicative verbs derived from -CV- roots in (35), except that all correspond to an underived-CVC- 
root. All these forms display a geminated /s/ consonant and those which have /a/ in the simplex root also manifest the vowel mutation characteristic of applicative morphology. Their analysis is not straightforward, since the underlying morphophonological processes are no longer active. One could assume that the causative suffix used to trigger the same kind of morphophonological changes on -CVC- roots as the applicative suffix still does today: suffix metathesis and umlaut effect on certain root vowels. The root-final consonant would then have assimilated to the consonant of the causative suffix. This would precisely be the reverse of what happens in case of contact between the root-final consonant and the consonant of the applicative suffix. ${ }^{11}$

$\begin{array}{ll}\text { Base verb } & \text { Causative } \\ \text { ka-yay } & \text { ka-yesse } \\ \text { 'appear' } & \text { 'make appear' } \\ \text { ka-bwar } & \text { ka-bwesse } \\ \text { 'get dressed' } & \text { 'dress (tr.)' } \\ \text { ka-bir } & \text { ka-bisse } \\ \text { 'lie down' } & \text { 'lay down' } \\ \text { ka-bol } & \text { ka-bosse } \\ \text { 'get soaked' } & \text { 'soak' } \\ \text { ka-lel } & \text { ka-lesse } \\ \text { 'cry' } & \text { 'make cry' } \\ \text { ka-wúl } & \text { ka-wússe } \\ \text { 'be, get full' } & \text { 'fill' } \\ \text { ka-lel } & \text { ka-lesse } \\ \text { 'hang (intr.)' } & \text { 'hang (tr.)' }\end{array}$

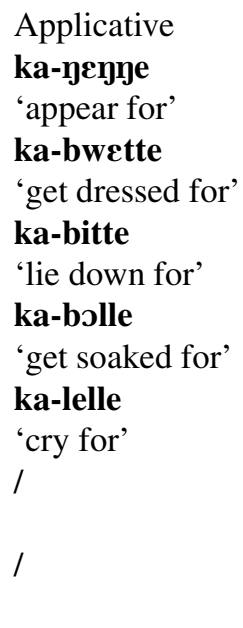

Alternatively, the derived causative verbs in (37) combine somehow applicative and causative morphology, just like the examples in (35), but it is not entirely clear how this could be properly analysed. We argued above that the suffix order is causative-applicative. In that case, one would expect consonant gemination on the causative suffix without affecting the verb root, generating forms like -yayisse, -bwatisse, etc. It might be, however, that maximality constraints on the length of the verb stem necessitated further shortening resulting in the

11. The morphophonological behaviour of the causative suffix in Tiene (B81) seems to support this analysis. Just like the /// of the applicative, the /s/ of the causative suffix is infixed into the root when the $\mathrm{C}_{2}$ of the root is not coronal, e.g., -lab-a 'walk' $\rightarrow$ lasab-a 'cause to walk', -lók-a 'vomit' $\rightarrow$-lósek-e 'cause to vomit'. When the root $\mathrm{C}_{2}$ is coronal, the /s/ of the causative replaces the $\mathrm{C}_{2}$, and the root vowel is lengthened, e.g., -tiit-a 'grow' $\rightarrow-\mathbf{- t i i s}-\boldsymbol{\varepsilon}$ 'cause to grow', -kol-o 'become tired' $\rightarrow$-koos-o 'tire (tr.)'. Given that the applicative and causative trigger similar morphophonological changes in Tiene, it is not unlikely that the same happened in Mbuun, even if the exact relationship between the facts observed in both languages is not established yet. 
causative forms observed in (37). The syntactic behaviour of some of these verbs seems to corroborate the assumption of a combined causative-applicative morphology. Even though none of these verbs has an inherently beneficiary meaning, some - not all - allow an extra beneficiary object without any further morphological change, as in (38b) vs. (38c). Others do not accept a supplementary beneficiary (B) or purpose (PURP) reading, as in (39d, f), and require the use of an oblique argument, as in $(39 \mathrm{c}, \mathrm{e})$, introduced by the polysemic preposition óngírá meaning 'for, in favour of, because of, due to'.

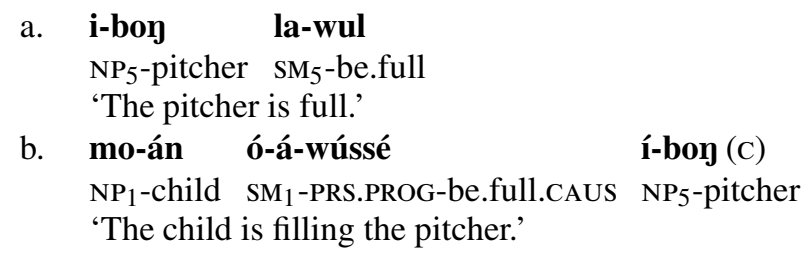

b. mo-án ó-á-wússé í-boy (c)

$\mathrm{NP}_{1}$-child $\mathrm{SM}_{1}$-PRS.PROG-be.full.cAUS $\mathrm{NP}_{5}$-pitcher 'The child is filling the pitcher.'

\section{c. mo-án ó-á-wússé máám (B) i-boy (C)}

$\mathrm{NP}_{1}$-child $\mathrm{SM}_{1}$-PRS.PROG-be.full.cAUs mother NP5-pitcher 'The child is filling the pitcher for my mother.'
a. a-sáy má-á-bol
$\mathrm{NP}_{6}$-millet $\mathrm{SM}_{6}$-PRS.PROG-ferment
'The millet is fermenting.'

b. maam o-á-bóssé á-say (c)

mother SM $_{1}$-PRS.PROG-ferment.CAUs $\mathrm{NP}_{6}$-millet

'Mother is making the millet ferment.'
c. maam o-á-bóssé á-say (c) óngira

mother $\mathrm{SM}_{1}$-PRS.PROG-ferment.CAUS $\mathrm{NP}_{6}$-millet for

\section{ma-n (PURP)}

$\mathrm{NP}_{6}$-beer

'Mother is making the millet ferment for (= to make) beer'

On the other hand, if consonant gemination has been grammaticalized as a marker of applicative morphology in Mbuun, the supplementary applicative 
use, which some of these causative verbs allow, could also be the result of reanalysis. The original causative morpho(phono)logy having become unproductive, the consonant gemination in these residual forms may have been reinterpreted as a sign of applicative morphology. Anyhow, it is obvious that the Proto-Bantu causative suffix *-ici- is no longer productive in Mbuun. This verbal derivational morpheme can only be observed sporadically in the lexicon.

\section{Causatives with applicative-like morphology}

Besides the canonical applicative verbs discussed in Section 3 and the residual causative verbs discussed in Section 4, Mbuun has several derived verbs, as in (40), which behave semantically and syntactically as causatives but which display typical applicative morphology, i.e., gemination of the root final consonant. Their semantic and syntactic behaviour largely corresponds to that of the verbs derived by means of the Proto-Bantu causative suffix *-ici-. Semantically speaking, as far as the available data allow us to judge, these applicative look-alike transitive verbs all seem to be derived from intransitive middle verbs. Following the classification of Kemmer (1993), the middle meanings of these base verbs can be subdivided into three classes. A first class of middle base verbs in Mbuun whose derived transitive verbs display applicative morphology are body action middles, also known as autocausatives (Creissels 2006; Geniušiene 1987; Voisin-Nouguier 2002). Such verbs, as in (40a), refer to actions carried out on or through one's own body, such as grooming, change in body posture, non-translational motion, and translational motion. A second class consists of anticausatives referring to processes that happen spontaneously (40b) (Haspelmath 1990; Kazenin 2001). A third category of verbs are either autocausative or anticausative depending on whether they have an animate and volitionally acting subject or not (40c).

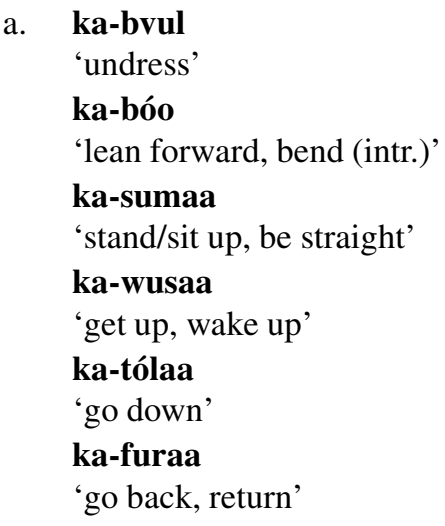

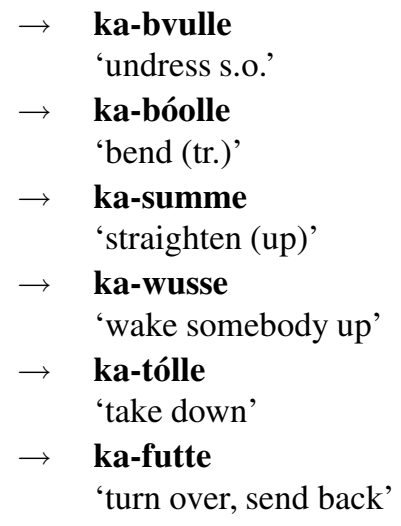




ka-téén mats
'swim'
ka-kóbaa
'put on weight'
ka-tóbaa
'get pierced, explode'
ka-wumaa
'swell'
ka-bumaa
'roll (intr.)'
ka-tumaa
'roll (intr.)'
ka-lóm
'leave, come out'
ka-shobaa
'slide, slip (intr.)'

$$
\begin{array}{ll}
\rightarrow \quad & \text { ka-téénne mats } \\
& \text { 'make swim'12 } \\
\rightarrow & \text { ka-kóbbe } \\
& \text { 'make fat' } \\
\rightarrow \quad & \text { ka-tóbbe/tóppe } \\
& \text { 'pierce, make explode' } \\
\rightarrow \quad & \text { ka-wumme } \\
& \text { 'make swell' } \\
\rightarrow \quad & \text { ka-bumme } \\
& \text { 'roll (tr.)' } \\
\rightarrow \quad & \text { ka-tumme } \\
& \text { 'roll (tr.)' } \\
\rightarrow \quad & \text { ka-lómme } \\
& \text { 'remove, take off/out' } \\
\rightarrow \quad & \text { ka-shobbe } \\
& \text { 'make slip' }
\end{array}
$$

Syntactically, as shown in (41)-(45), these morphologically applicative-like verbs behave like the residual causative verbs in (33) which are derived by means of the Proto-Bantu causative suffix *-ici-. The derived verb allows the introduction of a new subject participant with the thematic role of causer. The subject of the base verb becomes the causee object of the derived verb.

\section{a. m-baa yi-á-dzim}

$\mathrm{NP}_{9}$-fire $\mathrm{SM}_{9}$-PRS.PROG-go.out

'The fire is going out.'

b. maam o-á-dzimme m-baa

mother SM $_{1}$-PRS.PROG-go.out.APPL $\sim$ CAUS $\quad \mathrm{NP}_{9}$-fire 'My mother extinguishes the fire.'

a. ma-ts ma-á-bel

$\mathrm{NP}_{6}$-water $\mathrm{SM}_{6}$-PRS.PROG-boil

'The water is boiling.'

b. maam o-á-belle ma-ts

mother $\mathrm{SM}_{1}$-PRS.PROG-boil.APPL $\sim$ CAUS $\mathrm{NP}_{6}$-water 'Mother is boiling the water.'
a. i-lál
lá-á-bumaa
$\mathbf{J}$
ma-in
$\mathrm{NP}_{5}$-ball $\mathrm{SM}_{5}$-PRS.PROG-roll LOC $\mathrm{NP}_{6}$-ground
'The ball is rolling on the ground.'

12. The simple verb ka-téén means 'to trace, to draw a line', while the noun mats means 'water', generating the literal meaning 'to draw a line in/on the water'. 
b.

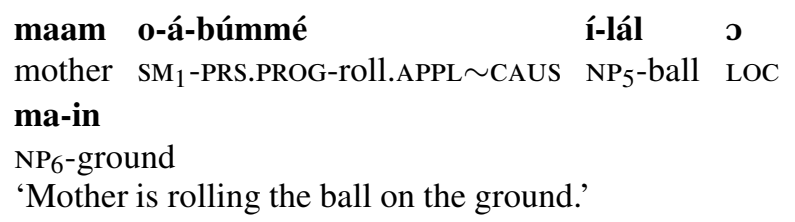

The examples in (44) show that the direct object of such a verb does not get the beneficiary reading, which canonical applicative verbs do allow. In contrast to true applicatives, which introduce a new object argument, these applicative look-alikes generally introduce a new subject argument with the semantic role of causer. Even if the subject in (44a) and (44b) remains lexically the same, it fulfils entirely different thematic roles in both sentences. In (44a), it functions as the typical subject of an autocausative verb, like -bumaa 'to roll (intr.), i.e. being at the same time the initiator and the endpoint of the expressed event (Kemmer 1993: 243). In (44b), mwăn 'child' is an agentive subject acting as a causer. Hence, the object ygwén 'his mother' of the derived verb in (44b) is always a causee, which does not act as a volitional entity, even if it has a human referent. The mother undergoes the action carried out by the child. The sentence in (44b) can therefore never be read as 'the child rolls on the ground for his mother'. This reading can only be obtained if ggwén 'his mother' is an oblique argument of the base verb -bumaa 'to roll (intr.)', as in (44c), where it is part of a typical beneficiary prepositional phrase introduced by óngírá.

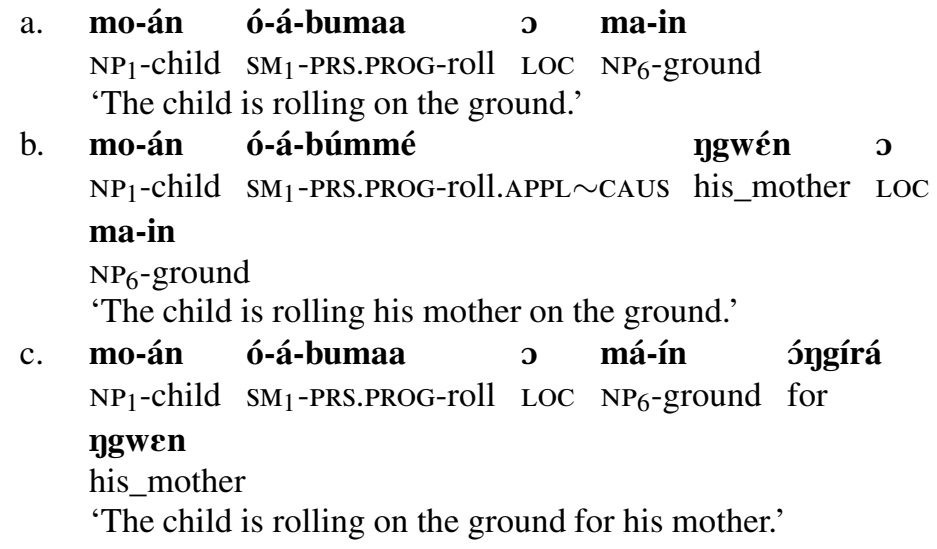

Certain intransitive verbs such as -bóo 'to bend' allow an internal object, very often a body part, such as áboy 'knees', generating the meaning 'to kneel' (45a). As shown in (45b), in this kind of construction, the object mwăn 'child' of the morphologically applicative-like derived verb, which corresponds to the subject of the underived verb, is also a causee and not a beneficiary. The newly 
introduced subject taar 'father' fulfils the semantic role of causer. The sentence in (45b) cannot get the beneficiary reading 'father kneels down for the child'. To obtain such a reading, mwăn has to be introduced again as an oblique argument of the underived verb as in (45c).
a. mo-án ó-á-bóó á-boy
$\mathrm{NP}_{1}$-child $\mathrm{SM}_{1}$-PRS.PROG-bend $\mathrm{NP}_{6}$-knee
'The child is kneeling down.'
b. taar o-á-bóóllé mó-án a-boy
father $\mathrm{SM}_{1}$-PRS.PROG-bend.APPL $\sim$ CAUS $\mathrm{NP}_{1}$-child $\mathrm{NP}_{6}$-knee
'Father is making the child kneel down.'
c. taar o-á-bóó á-boy óggírá mó-an
father $\mathrm{SM}_{1}$-PRS.PROG-bend $\mathrm{NP}_{6}$-knee for $\mathrm{NP}_{1}$-child
'Father is kneeling down for the child.'

In some cases, as in (46), a certain ambiguity is observed between a causative and beneficiary reading of applicative-like verbs derived from an intransitive verb, such as -bvúl 'to remove, take off', which allows a limited number of internal objects referring to garment, such as épis 'cloth' or mpú 'hat'. In the sentences in (46c) and (46d), the object táár 'father' is preferably interpreted as a causee, but informants do not refuse a beneficiary interpretation. In the latter case, the derived verb loses its causative meaning and behaves like an ordinary applicative. It simply adds a beneficiary connotation to the lexical meaning of the base verb. Even though such an ambiguity is not excluded, the beneficiary is still preferably introduced as an oblique argument of the underived verb as in (46e) and (46f).
a. maam o-á-bvúl
É-pis
mother $\mathrm{SM}_{1}$-PRS.PROG-remove $\mathrm{NP}_{7}$-cloth
'Mother is getting undressed.'
b. maam o-á-bvúl m-pú
mother SM $_{1}$-PRS.PROG-remove $\mathrm{NP}_{9}$-hat
'Mother is taking off her hat.'
c. maam o-á-bvúllé táár é-pis
mother $\mathrm{SM}_{1}$-PRS.PROG-remove.APPL $\sim \mathrm{CAUS}$ father $\mathrm{NP}_{9}$-cloth
i. 'Mother is undressing father.' ii. 'Mother is undressing for father.'
d. maam o-á-bvúllé táár m-pu
mother $\mathrm{SM}_{1}$-PRS.PROG-remove.APPL $\sim \mathrm{CAUS}$ father $\mathrm{NP}_{9}$-hat i. 'Mother takes off father's hat.' ii.' 'Mother takes off her hat for father.' 

e. maam o-á-bvúl é-pís óngírá táar mother $\mathrm{SM}_{1}$-PRS.PROG-remove $\mathrm{NP}_{7}$-cloth for father 'Mother is getting undressed for father.' (preferred)
f. maam o-á-bvúl m-pú óygírá táar mother $\mathrm{SM}_{1}$-PRS.PROG-remove $\mathrm{NP}_{9}$-hat for father 'Mother is taking off her hat for father.' (preferred)

The above described ambiguity is probably linked to the fact that most applicative-like causative verbs accept an extra beneficiary object without further morphological change, as in (47). This is only possible if the derived verb already has a causee object. Whether the beneficiary is introduced as a direct object or as an oblique argument, as in (47a) vs. (47b), the derived verb remains morphologically unchanged. If it is represented as a beneficiary direct object (B), it always precedes the causee object (C), which in its turn, precedes the patient object $(\mathrm{P})$, as in $(47 \mathrm{e})$. This corresponds to the object order after residual causative-applicative verbs built on the Proto-Bantu causative suffix *-ici-, cf. (36) and (38c).

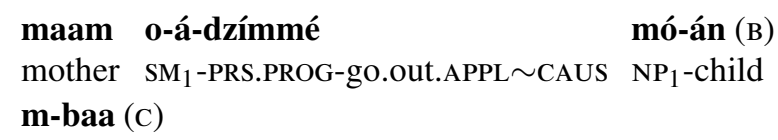


In other words, even if the morphologically applicative-like verbs in (40) behave primarily as causatives, they allow properties of the applicative, as long as causative syntax and semantics are respected.

\section{Towards an account: Semantic split}

The causative/applicative syncretism in Mbuun is relatively easy to describe, but more difficult to account for historically. In this section, we consider the possibility of semantic split as the origin of this phenomenon. As we have shown in Section 2, the morphology manifesting both applicative and causative uses in Mbuun is related to the Proto-Bantu applicative suffix *-Id-. Hence, if semantic shift is concerned, we have to start from the assumption that the semantic space of the applicative morpheme underwent an extension to cover causative meanings, and not the other way around.

Semantic shifts from meanings generally associated with the applicative to causative meanings have been reported in the literature, also in African languages. The verb 'to give', for example, having an inherently beneficiary meaning, not only regularly grammaticalizes as a benefactive marker, but also sometimes as a causative marker. It is equally observed as an auxiliary in analytical causative constructions, which often constitute an initial step towards grammaticalization (Heine \& Kuteva 2002: 149-152; Peterson 2007: 135; Voisin-Nouguier 2003: 194-195). Voisin-Nouguier (2003: 195-196) also points out that in certain African languages, such as Ijo and Sosso, causative markers originate from directional or comitative adpositions, which are primarily linked with applicative constructions. However, cases of true applicative markers developing causative uses are far less common in the literature and are far from unambiguous. One possible language group where the semantic shift took place in this direction are the so-called Bantu A70 languages from Cameroon and Gabon. These Bantu languages no longer have productive applicative morphology and their causative marker -əl is possibly a reflex of the Proto-Bantu applicative suffix *-Id- (Nzang-Bie 2008). If such was the case and if the causative/applicative syncretism in Mbuun resulted indeed from semantic split, the Mbuun causatives with applicative-like morphology could represent an analogous semantic evolution, though less advanced, since the applicative use is still highly productive. ${ }^{13}$

13. As we will demonstrate in more detail further on, the Bantu A70 causative marker -əl might as well have its origin in a derivational suffix which is phonologically similar to the applicative, e.g., the 'reversive'/'separative' suffix *-əd- (Meeussen 1967: 92; Schadeberg 2003: 77). Nzang-Bie (2008) does not consider this possibility. 
Semantic change from the causative towards the applicative is more widespread in the world's languages. As Shibatani \& Pardeshi (2002) demonstrate, causative morphemes are cross-linguistically often associated with the applicative function of introducing a comitative, instrumental or beneficiary argument. They cite examples from several Australian, Amerindian and Asian languages. They see the so-called 'sociative causatives' as an important source for the applicative reinterpretation of causative morphology. 'Sociative causation' constitutes an intermediate category between direct and indirect causation. It concerns most typically the kind of situation whereby a causer makes the causee perform a certain action by simultaneously carrying out the action him/herself, for instance to make someone cry by crying yourself or to make someone run by running yourself. Besides such joint-action sociatives, Shibatani \& Pardeshi (2002: 100) distinguish two other types of sociative construction: assistive (e.g., 'to make someone pee') and supervision (e.g. 'to make someone read'). Like direct causation, sociative causation involves a spatio-temporal overlap between the action of the causer and causee often entailing physical involvement of the causer in the caused event, certainly in the case of joint-action and assistive sociatives. On the other hand, the involvement of two agentive participants in sociative causation bears resemblance with indirect causation. In particular, supervision sociatives, which are characterized by a physical separation between causer and causee, are close to indirect causatives. Sociative causatives thus constitute a continuum themselves between direct and indirect causatives. In certain languages, the three situation types are expressed in a different way. In most languages, however, sociative causation shares its formal expression with one of the other kinds of causation. Cross-linguistically, different causative forms are differently distributed over the causative continuum, as Shibatani \& Pardeshi (2002: 102) clearly illustrate. Closely related to this sociative use is the so-called 'adjutive' meaning, i.e. 'to help to do', which the reflex of the causative suffix *-ici- expresses in certain Bantu languages, mainly in the southeast (Schadeberg 2003: 73). Via such sociative meanings, causatives may become associated with typical applicative uses. They frequently become markers of comitative constructions. A comitative reading is easily derived, for instance, from joint-action causatives, a meaning such as 'to make someone walk' being re-interpreted as 'to walk with someone'. Instrumental and beneficiary meanings are less easily obtained from such causatives. However, assistive sociatives referring to the assistance of someone to do something may give rise to a benefactive reading. Instrumental uses of causative markers may develop from their comitative function, but they may also emerge independently from sociative and/or comitative constructions. Such is the case in certain Bantu languages, where the Proto-Bantu causative marker *-ici- may act as an instrumental applicative, as shown by the Kinyarwanda example from Kimenyi (1988: 367-368) in (48), cited by Vois- 
in-Nouguier (2003) and Shibatani \& Pardeshi (2002). In (48a), the instrument í́karámu 'pen' preceded by the comitative preposition n(a) 'with' is introduced as an oblique argument of the base verb -andika 'to write'. In (48b), the same instrumental participant is introduced after the patientive object íbarúwa 'letter' as a second direct object of the derived verb -andikiisha marked by the causative suffix -iish-.

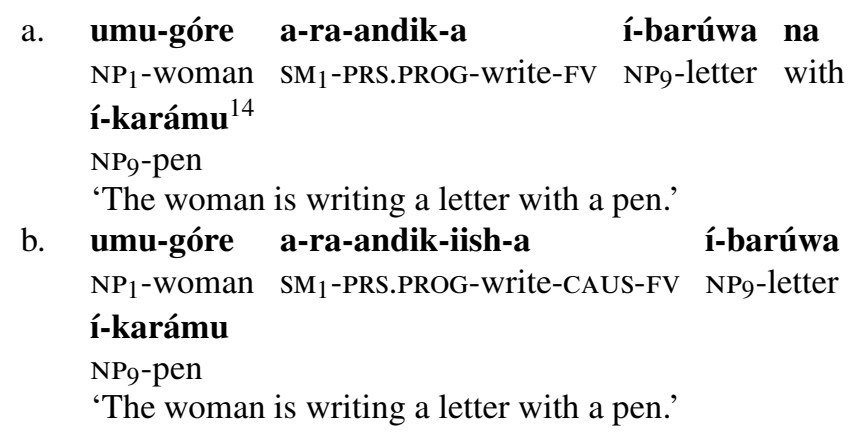

Similar instrumental uses of the Proto-Bantu causative marker *-ici- have been reported in other Bantu languages, for instance in Shona (Fortune 1955: 215; cited by Peterson 2007: 66) or Zulu, Tonga, Ila, Kwanyama and Ganda (Wald 1998: 97) (cited by Voisin-Nouguier 2003: 190). Applicative/causative syncretism is thus certainly not nonexistent in Bantu. However, like in most other languages of the world, the direction of evolution is from causative to applicative and not the other way around as in Mbuun, provided that the causative/ applicative syncretism in Mbuun effectively resulted from semantic split.

Moreover, in languages attesting a causative/applicative syncretism, the split between causative and applicative readings is often tied to verbal semantics. It often coincides with the division between unaccusative or inactive intransitive and other predicates. Unaccusative verbs trigger a causative reading, while unergative or active intransitive and transitive bases trigger an applicative reading (Peterson 2007: 133; Shibatani \& Pardeshi 2002: 116). According to Shibatani \& Pardeshi (2002), such subdivision is found especially with causative suffixes, which are semantically closer to the direct causation pole of the causative continuum and which have undergone a high degree of lexicalization. Such suffixes involve an agentive causer and a patientive causee and cannot host two agents. That is why only forms derived from inactive intransitive verbs take a causative meaning, while the same morpheme develops applicative meanings when it is associated with forms derived from other predicates, 
which can host two predicates. In Mbuun, as shown in (40), the causative reading of applicative look-alike forms is associated with intransitive base verbs, but not specifically with unaccusative predicates. It is associated with both inactive and active intransitive verbs. ${ }^{15}$ However, the derived forms of both types of intransitive base verbs express direct causation involving an agentive causer and a patientive causee. The split between causative and applicative readings in Mbuun thus seems to be somehow tied to verbal semantics, but in a different way from the languages considered by Shibatani \& Pardeshi (2002). This could be due to the fact that the causative/applicative syncretism in Mbuun finds its origin in an applicative construction and not in a causative as in most other languages. Cross-linguistically, applicatives from intransitive base verbs are slightly more marked than those derived from transitive base verbs (Polinsky 2008). The applied object of applicativized intransitives is more often associated with the more peripheral semantic roles of instrument, goal or location than with that of beneficiary. In Sesotho (S33), for instance, applied objects of applicatives derived from unaccusative intransitives, as in (49a) vs. (49b), or from intransitives of motion, as in $(49 \mathrm{c})$ vs. ( $49 \mathrm{~d}$, e), are most commonly associated with the thematic roles of either location or goal (Demuth 1998).The morphological analysis and the glossing of these Sesotho examples are ours.
a. di-ntja di-hol-a kapele
$\mathrm{NP}_{10}$-dog $\mathrm{SM}_{10}$-grow-FV fast
'Dogs grow fast.'
b. di-ntja di-hol-el-a kapele se-robe-eng
$\mathrm{NP}_{10}$-dog $\mathrm{SM}_{10}$-grow-APPL-FV fast $\mathrm{NP}_{7}$-barn-LOC
'Dogs grow up fast in the barn.'
c. ba-nana ba-math-a le-bala-eng
$\mathrm{NP}_{2}$-girls $\quad \mathrm{SM}_{2}$-run-FV $\mathrm{NP}_{5}$-playground-LOC
'The girls are running in the playground.'
d. ba-nana ba-math-el-a le-bala-eng
$\mathrm{NP}_{2}$-girls $\quad \mathrm{SM}_{2}$-run-APPL-FV $\quad \mathrm{NP}_{5}$-playground-LOC
'The girls are running to/in the playground.'
e. Banana ba-math-el-a ntate le-bala-eng
$\mathrm{NP}_{2}$-girls $\mathrm{SM}_{2}$-run-APPL-FV father $\mathrm{NP}_{5}$-playground-LOC
'The girls are running for/to my father in the playground.'

15. Comparable to the applicative-like causatives in Mbuun, the applicative marker -e in Wolof may also generate lexicalized causative meanings with both active and inactive intransitive base verbs, such as 'leave, come out', 'return, go back', 'scatter', 'go down', 'stay', 'be called', 'be forbidden' (Voisin-Nouguier 2003). 
As discussed in Section 3, certain active intransitive base verbs can be applicativized in Mbuun. Just like in Sesotho, the applied object generally does not have the prototypical thematic role of beneficiary in such cases. It is primarily associated with less central thematic roles, most often 'reason' (R), but also 'goal' (G), as the examples in (50) demonstrate. If the applied object can get a beneficiary (or maleficiary) reading, as in (50f-i), it is always secondary.
a. mo-án
ó-á-léllé
máam
$\mathrm{NP}_{1}$-child $\mathrm{SM}_{1}$-PRS.PROG-cry.APPL mother
'The child is crying because of mother.' (reason)
b. mo-án ó-á-syéllé máám mó-as
$\mathrm{NP}_{1}$-child $\mathrm{SM}_{1}$-PRS.PROG-put.APPL mother $\mathrm{NP}_{3}$-yawn
'The child is yawning due to mother.' (reason)
c. mo-án ó-á-mwétté máam
$\mathrm{NP}_{1}$-child $\mathrm{SM}_{1}$-PRS.PROG-Smile.APPL mother
'The child is smiling because of mother.' (reason)
d. mo-án ó-á-kwébbé máam
$\mathrm{NP}_{1}$-child $\mathrm{SM}_{1}$-PRS.PROG-fatten.APPL mother
'The child is putting on weight because of mother.' (reason)
e. mo-án ó-á-yéyyé máam
$\mathrm{NP}_{1}$-child $\mathrm{SM}_{1}$-PRS.PROG-appear.APPL mother
'The child is appearing because of mother.' (reason)
f. m-bwá ó-á-béllé mó-an

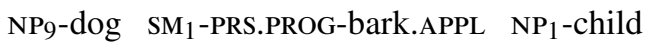
'The dog is barking due to/at the child.' (reason/maleficiary)
g. mo-án ó-á-tóómmé táar o ma-in
$\mathrm{NP}_{1}$-child $\mathrm{SM}_{1}$-PRS.PROG-jump.APPL father LOC $\mathrm{NP}_{6}$-ground
'The child is jumping on the ground because of/for father.' (rea- son/beneficiary)
h. mo-án ó-á-tsíillé máam
$\mathrm{NP}_{1}$-child $\mathrm{SM}_{1}$-PRS.PROG-come.APPL mother
'The child comes to/for mother.' (goal/beneficiary)
i. mo-án ó-á-kwénné máam
$\mathrm{NP}_{1}$-child $\mathrm{SM}_{1}$-PRS.PROG-walk.APPL mother
'The child walks to/for mother.' (goal/beneficiary)

Given that applicative-like forms with causative meaning are only found with intransitive base verbs, verbal semantics seems to play a role in the causative/ applicative syncretism in Mbuun. However, the split between causative and applicative readings does not coincide neatly with the split between intransitive and transitive verbs, since active intransitive verbs are also found with applicative meanings, though only rarely with the prototypical applicative semantic role of beneficiary. This could be linked to the fact that the applicative mor- 
phology involved is still very productive in Mbuun. This is in contrast to the languages considered by Shibatani \& Pardeshi (2002) where morphemes which display a neat causative/applicative split defined by verbal semantics also manifest a high degree of lexicalization.

In sum, if the causative/applicative syncretism in Mbuun was the outcome of semantic split, it would be typologically odd in several respects. To begin with, it would result from a semantic shift from applicative to causative, which is universally far more exceptional than semantic change in the opposite direction. Furthermore, it is connected with verbal semantics in a way which differs from most other cases of causative/applicative syncretism. The split between causative and applicative readings coincides with the dividing line between intransitive and transitive verbs and not between unaccusative predicates and the rest. This divide is not absolute, since forms derived from active intransitive verbs can be either causative or applicative.

\section{Towards an account: phonemic merger}

In this section, we consider the possibility of phonemic merger as a possible historical explanation for the applicative/causative syncretism observed in Mbuun synchronically. Phonemic merger is the process by which two separate phonemes end up as a single phoneme which results in minimal pairs becoming homophones or homonyms (Crowley 1992: 79). If phonemic merger applied in this case, it would imply that the causative verbs with applicative morphology were originally distinct in shape from the true applicative forms, but became identical through convergent (morpho)phonological change. If such was the case, the applicative-like causatives could not stem from the Proto-Bantu causative suffix*-ici-, whose residual forms look different in Mbuun, as shown in Section 4. There are some indications that the applicative-like causatives originated indeed from another morpheme than the Proto-Bantu applicative suffix *-Id-.

Firstly, the applicative-like causatives look very much like applicatives, in that they also involve consonant gemination, but some rare examples show that their morphophonological behaviour is not exactly the same. As discussed in Section 2 and illustrated by the examples in (5), the applicativization of certain verb roots is accompanied by an umlaut effect turning the root vowel /a/ into $/ \varepsilon /$ when it is short and into /ee/ when it is long. As shown in (51a), we found at least one example of a derived causative verb manifesting root final consonant gemination, but no umlaut effect on the root vowel /a/. There are more of such forms combining a geminated root final consonant with the root vowel /a/. The consonant gemination suggests that these forms are historically derived. Synchronically, however, they no longer correspond to an underived base verb. 
The fact that the root vowel /a/ of the verbs in (51b) did not undergo an umlaut effect indicates that the derivational suffix involved in these forms is not the Prot-Bantu applicative suffix *-Id-.

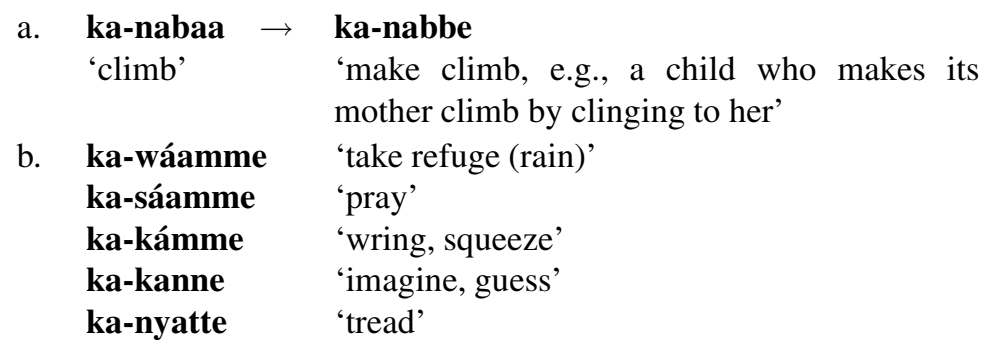

Interesting enough, these forms do manifest an umlaut effect, when they take an extra object with the semantic role of beneficiary, goal or reason, as shown in (52a) vs. (52b), (53a) vs. (53b) and (54a) vs. (54b). Since these thematic roles are typically associated with applied objects, it can be assumed that the applicative suffix is involved in these forms. In (53c) and (54c), the verbs -kámme and -sáamme take an extra object, but do not undergo the umlaut effect. In these cases, the object does not get a beneficiary reading. It assumes the semantic role of causee, while the verb itself acts as a true causative like -nabbe 'make climb' in (52a), which is derived from -nabaa 'climb'. The verbs -kámme and -sáamme no longer correspond to an underived base verb. Their causative behaviour in (53c) and (54c) suggests they may originally have been true causatives, but underwent semantic change once their base verb became obsolete.

a. mo-án ó-á-nábbé máam

$\mathrm{NP}_{1}$-child $\mathrm{SM}_{1}$-PRS.PROG-climb.APPL $\sim$ CAUS mother

'The child is making mother climb.'

b. mo-án ó-á-nćbbé máam

$\mathrm{NP}_{1}$-child $\mathrm{SM}_{1}$-PRS.PROG-climb.APPL mother

'The child is climbing due to mother/to mother'

a. maam o-á-kámmé

má-íts a m-ba

mother SM $_{1}$-PRS.PROG-squeeze $\mathrm{NP}_{6}$-oil CONN NP9-palm_nut

'Mother is squeezing oil from the palm nut.'

b. maam o-á-kémmé mó-án má-íts

mother $\mathrm{SM}_{1}$-PRS.PROG-squeeze.APPL $\mathrm{NP}_{1}$-child $\mathrm{NP}_{6}$-oil

a $\mathbf{m}-\mathbf{b a}$

CONN NP9-palm_nut

'Mother is squeezing palm oil for the child.' 


\section{c. maam o-á-kámmé}

mó-án má-íts a

mother $\mathrm{SM}_{1}$-PRS.PROG-squeeze $\mathrm{NP}_{1}$-child $\mathrm{NP}_{6}$-oil CONN

m-ba

$\mathrm{NP}_{9}$-palm_nut

'Mother is making the child squeeze palm oil.'

a. maam o-á-saamme

mother SM $_{1}$-PRS.PROG-pray

'Mother is praying.'

b. maam o-á-séémmé

mó-an

mother $\mathrm{SM}_{1}$-PRS.PROG-pray.APPL $\mathrm{NP}_{1}$-child

'Mother is praying for the child.'

maam o-á-sáámmé mó-an

mother $\mathrm{SM}_{1}$-PRS.PROG-pray $\mathrm{NP}_{1}$-child

'Mother is making the child pray.'

Mbuun has additional morphologically complex verbs which look like derived applicative verbs, but which are also pseudo-applicatives in that they can neither be synchronically linked with a non-applicative base verb nor have typical applicative semantics. The verbs in (55) have a root vowel other than /a/ implying that the umlaut effect triggered by the applicative suffix would not be visible anyhow. However, another verb root extension was possibly also involved in their formation.

$\begin{array}{ll}\text { ka-solle } & \text { 'to discover, find' } \\ \text { ka-bóomme } & \text { 'to abandon' } \\ \text { ka-kulle } & \text { 'to scrape, sculpt' } \\ \text { ka-kyelle } & \text { 'to cut' } \\ \text { ka-kólle } & \text { 'to cough' } \\ \text { ka-yíppe } & \text { 'to lean' } \\ \text { ka-lélle } & \text { 'to shrink' }\end{array}$

Another indication that the morphophonological behaviour of applicative-like causatives is not exactly the same as that of true applicatives is the fact that the diphthongization of the root vowels $/ \mathbf{J} /$ and $/ \mathbf{o} /$ never takes place in these forms. As we have shown in Section 2, example (7), this mutation occurs systematically when the applicative form of such roots takes a 1sG object marker. As shown in (56), neither applicative-like causatives, as those in (40), nor pseudo-applicatives, as those in (55), ever manifest such diphthongization, not even when they take a 1 sG object marker. 


\begin{tabular}{|c|c|c|c|}
\hline $\begin{array}{l}\text { n-lóomme (mme) } \\
\text { 'take me out' }\end{array}$ & vs. & $\begin{array}{l}\text { mó-lóomme } \\
\text { 'take him out' }\end{array}$ & (<-lóom) \\
\hline $\begin{array}{l}\text { n-tóbbe (mme) } \\
\text { 'pierce me' }\end{array}$ & vs. & $\begin{array}{l}\text { mó-tóbbe } \\
\text { 'pierce him' }\end{array}$ & ( <-tóbaa) \\
\hline $\begin{array}{l}\text { m-bóomme (mme) } \\
\text { 'abandon me' }\end{array}$ & vs. & $\begin{array}{l}\text { mó-bóomme } \\
\text { 'abandon him' }\end{array}$ & \\
\hline $\begin{array}{l}\text { n-sólle (mme) } \\
\text { 'find me' }\end{array}$ & vs. & $\begin{array}{l}\text { mó-sólle } \\
\text { 'find him' }\end{array}$ & \\
\hline
\end{tabular}

Both the umlaut effect on root vowel /a/ and the diphthongization of the root vowels $/ \mathbf{s} /$ and $/ \mathbf{o} /$ are triggered by a front vowel in the following syllable. The fact that these sound changes never occur with these applicative-like causatives or pseudo-applicatives suggests that the Proto-Bantu applicative suffix *-Id- is not involved in their structure. On the other hand, the fact they also display consonant gemination indicates that the derivational suffix involved must be phonologically similar, but without a front vowel.

Crucial in this respect is the existence of a few derived verbs in Mbuun, such as those in (57), which have a 'reversive' or 'separative' meaning and also manifest consonant gemination, but no umlaut effect.

$$
\begin{array}{lllll}
\text { ka-dzubaa } & \text { 'to close (tr.)' } & \rightarrow & \text { ka-dzubbe } & \text { 'to open (tr.)' } \\
\text { ka-kay } & \text { 'to close (tr.)' } & \rightarrow & \text { ka-kayge } & \text { 'to open (tr.)' }
\end{array}
$$

It is well-known that one of the 'reversive' or 'separative' derivational suffixes reconstructed for Proto-Bantu is *-vd- (Meeussen 1967: 92; Schadeberg 2003: 77). It ends in the same consonant as Proto-Bantu applicative suffix*-Id-, often a liquid in present-day Bantu languages, but has a back vowel with the same degree of aperture instead of a front vowel. This explains why its morphophonological behaviour in Mbuun is similar to that of the applicative but not identical with it. It involves consonant gemination through the contact between the root final consonant and the suffix consonant. Nevertheless, it lacks the umlaut or diphthongization of the root vowel, which is triggered by the front vowel of the applicative suffix. The involvement of the PB 'separative' suffix *-vd- in the derived forms in (57) is corroborated by the lexical reconstruction *-kangud- 'open' (Bastin et al. 2002).

The question is whether it is plausible that the same 'separative' suffix is involved in the applicative-like causative verbs treated above. In this respect, it is important to stress, as Schadeberg (2003: 78) does, that the suffix *-vd- is found with meanings other than 'separative' in Bantu, 'intensive' and 'repetitive' being the most recurrent (Dammann 1959). Its polysemic nature ties in with the fact that this suffix is never fully productive in Bantu. It is frequently observed, but cannot be freely used to derive 'separative' forms from base verbs (Schadeberg 2003: 77). It is more lexicalized than other derivational verb suf- 
fixes, such as the applicative, causative, reciprocal or passive. Derived verbs containing this suffix are more prone to idiosyncratic semantic change. The original meaning of the suffix is therefore more easily obscured. What is even more important is that the suffix*-od- usually derives transitive 'separative' verbs and regularly commutes with its intransitive equivalent *-vk-, leading to pairs such as the Makwe (G402) examples in (58) (Devos 2008: 203).

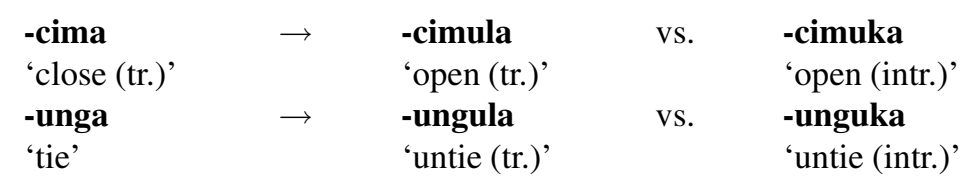

The use of the suffixes *-vk- and *-vd- is lexicalized to such an extent that Bantu languages often have extended verb stems, which involve one or both of them, but no longer have the underived base verb. As shown in (59), the Bantu Lexical Reconstructions III database contains several pairs of such extended *-øk- and *-ød- verbs for which a simplex verb root was not reconstructed (Bastin et al. 2002).
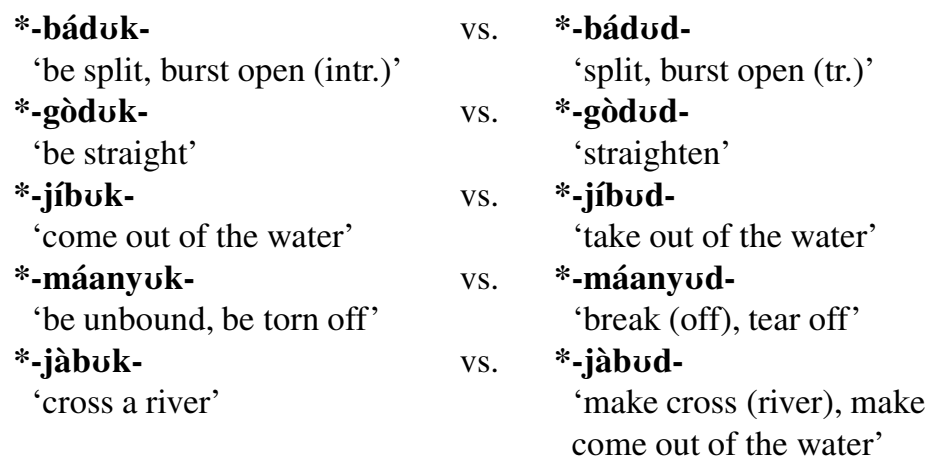

In most extended verbs in (59), an original 'separative' semantic element might still be perceptible, but the suffixes *-vk- and *-vd- can no longer be considered as truly derivational in the absence of an underived base verb. In such pairs, *-vd- marks the transitive member which makes it similar to true causative suffixes, especially when the latter act on intransitive predicates. The extended *-vd- verbs in (59) relate to their intransitive *-vk- counterparts in the same way as derived causative verbs relate to their intransitive base verbs. Moreover, the reconstructed verbs with *-wd- have an implied 'causative' sense to them. This semantic affinity is furthermore corroborated by the fact that the suffix is observed with both reversive and causative meanings in certain languages. In Mongo, for instance, the reflex of *-wd- is polysemic. Its essential meaning is reversive (60a), but it is also found with several peripheral mean- 
ings, such as iterative, augmentative and causative (60b) (Hulstaert 1965: 272; cited by Schadeberg 2003: 78).

a. Reversive

$\begin{array}{lllll}\text {-ís- } & \text { 'hide' } & \rightarrow & \text {-ís-ol- } & \text { 'discover' } \\ \text {-kúk- } & \text { 'cover' } & \rightarrow & \text {-kúk-ol- } & \text { 'uncover' } \\ \text {-kund- } & \text { 'bury' } & \rightarrow & \text {-kund-ol- } & \text { 'dig up' } \\ \text { Causative } & & & & \\ \text {-ám- } & \text { 'swell' } & \rightarrow & \text {-ám-ol- } & \text { 'make swell' } \\ \text {-láng- } & \text { 'listen' } & \rightarrow & \text {-láng-ol- } & \text { 'make listen' } \\ \text {-tsí- } & \text { 'drift' } & \rightarrow & \text {-tsí-ol- } & \text { 'make drift, divert' }\end{array}$

Causative meaning may thus occur as a peripheral extension of the semantic reversive core of *-vd-. Hence, this suffix appears to be a plausible origin for the applicative-like causatives in Mbuun. Since this shift from the original reversive/separative core meaning to causative meaning ties in with the highly lexicalized nature of $*$-vd-, it could well be an evolution, which transcends Mbuun as such. Noteworthy in this respect is the observation that several of the causative verbs in (40) have a base verb, which ends in the vowel /a/. The canonical underived verb root structure in Mbuun is CVC. Moreover, the language is characterized by final vowel loss and allows for closed CVC syllables. Unlike in most Bantu languages, a verb or noun stem does not need to end in a vowel. Hence, even if these verbs no longer correspond to a simplex root, the presence of a final $/ \mathrm{a} /$ in these intransitive base verbs suggests derivational morphology. As a real derivational suffix, -aa is only found with a limited number of base verbs from which it derives a neutro-passive meaning (61) (Mundeke 2006: 72).

$$
\begin{array}{ll}
\text { ká-ból 'to beat' } & \rightarrow \text { ká-ból-aa 'to be beaten' } \\
\text { ká-món 'to see' } & \rightarrow \text { ká-món-aa 'to be seen' } \\
\text { ká-tón 'to build' } & \rightarrow \text { ká-tón-aa 'to be built' } \\
\text { ká-sal 'to hoe, weed' } & \rightarrow \text { ká-sal-aa 'to be weeded' } \\
\text { ká-láám 'to prepare, cook' } \rightarrow \text { ká-láám-aa 'to be cooked' }
\end{array}
$$

This -aa suffix is reminiscent of the Proto-Bantu 'positional' suffix *-am-, which typically conveys a specific kind of middle meaning, namely 'assuming a position' or 'being in a position' (Schadeberg 2003: 75). This is precisely the sense some of the -aa final base verbs in (40) have, e.g., -sumaa 'stand/sit up, be straight', -wusaa 'get up, wake up'. The other -aa final base verbs, to which applicative-like causatives are associated, have closely related autocausative and/or anticausative middle meanings, which can be easily derived from the core meaning of *-am-. Moreover, this middle suffix is known to have become a passive suffix in certain Bantu languages (Schadeberg 2003: 76), which are 
semantically close to the neutro-passive meaning of the derived verbs in (61). It can therefore be safely assumed that the -aa final middle verbs in (40) and the neutro-passive verbs in (61) are historically related and involve the Proto-Bantu 'positional' suffix *-am-.

It is well-known that the suffix *-am- constitutes a kind of derivational subsystem with the suffix pair *-vk- $/ *$-vd- and the 'impositive' suffix *-rk-, in the sense that these suffixes frequently commute with each other, while alternation with an underived base verb is less frequent (Meeussen 1967: 92; Schadeberg 2003: 74). This makes it all the more likely that the applicative-like causatives in Mbuun are actually built on the suffix *-vd-. As illustrated in (62), certain applicative-like causatives and the -a final verbs with which some of them commute can indeed be associated with existing Bantu lexical reconstructions involving at least one of the suffixes of the derivational subsystem *-vk- /*-vd- /*-am- / *-Ik-.

\begin{tabular}{|c|c|c|c|}
\hline ka-tólaa & 'go down' & $\approx *$-tú(v)duk- & 'come down' \\
\hline ka-tólle & 'take down' & & \\
\hline ka-tólaa & 'go back, return' & $\approx *$-bútuk- & 'go back' \\
\hline ka-futte & 'send back' & & \\
\hline ka-tóbaa & 'get pierced' & 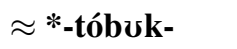 & 'be pierced', \\
\hline ka-tóbbe & 'pierce' & *-tóbud- & 'pierce' \\
\hline ka-kámme & 'squeeze' & 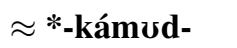 & 'wring, squeeze' 16 \\
\hline ka-kúlle & 'scrape, sculpt' & $\approx *$-kvdud- & 'scrape' \\
\hline ka-kólle & 'cough' & 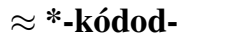 & 'cough' \\
\hline
\end{tabular}

In sum, all these indications make it highly plausible that (partial) syncretism between the applicative suffix *-Id- and the transitive 'reversive' suffix *-odhad a fair share in the emergence of the applicative/causative syncretism in Mbuun. Affixed to the verb root, both suffixes trigger nearly the same morphophonological changes involving consonant gemination and making their surface forms very similar or in most cases even indistinguishable. The causative semantics of the suffix *-vd- find their origin in its strong degree of lexicalization. No longer commuting with a simplex verb root, its transitive 'reversive' meaning developed into the transitivizing effect, which is generally associated with causatives.

16. The verb *-kámud- 'wring, squeeze' was actually reconstructed with the same meaning as the underived verb *-kám- 'wring, squeeze'. As shown in (52), the verb -kámme in Mbuun acts as an ordinary transitive verb taking a patient object when it has only one object, but as a true causative when it gets an extra object. The reflex of the simplex root *-kám- does not exist in Mbuun. The fact that the simple verb and the extended verb were reconstructed with the same meaning may support our assumption that the extended verb was originally a true derived causative, but underwent semantic change once its base verb got lost. 


\section{Grammaticalization of consonant gemination as a marker of applica- tive morphology}

From what precedes, it has become clear that (partial) phonemic merger of the Proto-Bantu derivational suffixes *-vd- and *-Id- is the most plausible historical scenario underlying the applicative/causative syncretism in Mbuun. It is more convincing than the assumption of a semantic extension of the suffix *-Id- from typical applicative functions to causative use. Quite the opposite, the applicative suffix *-Id- seems to have profited from the (partial) syncretism with *-vd- to expand its action radius. This formal similarity enabled extended verbs built on *-vd- to take up secondary applicative functions without additional morphological modification. As we show at the end of Section 5, certain causative verbs marked by a geminated root-final consonant accept an extra object with a typical applicative semantic role, most often beneficiary, without specific applicative marking, see (47). Such an extra applied object is only accepted in the presence of a causee object suggesting that the applicative use is secondary and only allowed when the causative function is fulfilled. Similar behaviour is observed with verbs which display consonant gemination but which no longer correspond to an underived base verb and which do not have a primary applicative function. We listed some of these verbs in (51b) and (55) above. We showed in (62) that at least some of them are built on the extension *-vd-. Just like true causatives involving consonant gemination, they accept an extra beneficiary object, but without requiring the presence of a causee object, as shown in (63). The verb -kúlle 'to sculpt' takes the patient object ote 'tree' in (63a), while it accepts in (63b) the extra beneficiary object mwăn 'child' without further morphological modification. The sentence in (63b) could not get the causative reading 'my father makes the child sculpt a tree'. A similar behaviour is observed with intransitive verbs, such as -lélle 'to shrink', which occasionally take an internal object like mbyel 'legs' as in (64a). As seen in (64b), such verbs also accept an extra beneficiary object without further morphological modification.

a. taar o-á-kúllé ó-te

father $\mathrm{SM}_{1}$-PRS.PROG-Sculpt $\mathrm{NP}_{3}$-tree

'My father is sculpting a tree.'

b. taar o-á-kúllé mó-án ó-te

father $\mathrm{SM}_{1}$-PRS.PROG-sculpt(.APPL) $\mathrm{NP}_{1}$-child $\quad \mathrm{NP}_{3}$-tree

'My father is sculpting a tree for the child.'

a. taar o-á-léllé m-byéel

father SM $_{1}$-PRS.PROG-shrink NP9-leg $^{-}$

'My father is checking his step (= is slowing down).' 


\section{b. taar o-á-lélle mó-án m-byéel \\ father $\mathrm{SM}_{1}$-PRS.PROG-shrink(.APPL) $\mathrm{NP}_{1}$-child $\mathrm{NP}_{9}$-leg \\ 'My father is checking his step for the child.'}

As we mentioned earlier, the verb -kúlle is probably a reflex of *-kwd-vd-. Even if the applicative suffix *-Id- is not historically involved in the derivation of these verbs, they accept secondary applicative functions, because they are morphologically similar to true applicative verbs. The minor differences in the morphophonological realisation of the suffixes *-Id- and *-vd- in Mbuun only become apparent in very specific contexts, for instance when the root vowel is /a/. Given that applicative morphology is still fully productive in Mbuun, in contrast to the lexicalized remains of *-vd-, the latter can easily be reanalysed as applicatives. This corroborates our analysis of consonant gemination in applicative verbs derived from -CV- roots, where the presence of a geminated /// can by no means be morphophonologically accounted for, see Section 2, examples in (9a). Hence, the secondary applicative use of historically non-applicative verbs is not so much the result of a true semantic extension from causative to applicative meaning, which underlies the causative/applicative syncretism in certain languages, as discussed in Section 6. It rather indicates that analogical extension made consonant gemination grammaticalize as a sign of applicative morphology.

\section{Conclusions}

The verb stem in Mbuun is limited to a maximum of two syllables. This had a considerable impact on the productivity of verbal derivation suffixes as well as on their ability to be added to a stem. The Proto-Bantu applicative suffix *-Id- remained fully productive and can be combined with the reciprocal/associative suffix, due to its particular morphophonological realization. The applicative morpheme adopts a -CV structure instead of the more common-VC shape. The direct contact between the final root consonant and the consonant of the applicative suffix entails the full assimilation of the latter and results in a geminated consonant. In contrast to the high productivity of the applicative suffix, the Proto-Bantu long causative suffix *-ici- is only observable in the lexicon. It is no longer synchronically productive. Mbuun also has a series of causative verbs, which look morphophonologically like applicatives. All of them are derived from intransitive base verbs, which have "middle" semantics. The origin of this causative/applicative syncretism in Mbuun does not seem to be the outcome of semantic split, as is the case in many other languages of the world, but rather the result of a phonemic merger due to the convergent phonological evolution of two morphemes, which were originally distinct, namely the applicative suffix *-Id- and the transitive reversive/separative suffix *-od-. 
The latter suffix, being less productive and more lexicalized than other verbal derivational suffixes in Bantu, displays a cross-linguistic variety of meanings which are more or less peripheral to its core reversive/separative meaning. The causative function that *-vd- fulfils in Mbuun is one of these secondary uses, which is also attested in other Bantu languages. It developed out of the transitivizing effect, which this suffix originally had in contrast to its intransitive counterpart *-vk-. However, even if these applicative-like causatives are historically distinct from true applicatives built on *-Id-, most of them do adopt secondary applicative properties. This is due to the fact that the root final consonant gemination they manifest has become so strongly associated with the applicative. The grammaticalization of consonant gemination as a marker of applicative morphology is not only evidenced by the fact that causative verbs which are not applicative in origin may adopt an applied object, but also by the presence of a geminated consonant in applicative forms where it cannot be morphophonologically accounted for, such as - CV- roots.

Ghent University (Belgium)

Royal Museum for Central Africa, Tervuren (Belgium)

Université libre de Bruxelles (Belgium)

koen.bostoen@ugent.be

Centre de Linguistique Théorique et Appliquée, Kinshasa (DR Congo)

mundekeleon@yahoo.fr

\begin{tabular}{ll}
\multicolumn{2}{l}{ Abbreviations } \\
$*$ & proto form \\
$* *$ & ungrammatical, non-existent \\
APPL & applicative \\
APPL CAUS & applicative-like causative \\
CAUS & causative \\
CONN & connective \\
FV & final vowel \\
LOC & locative \\
MID & middle \\
$\mathrm{NP}_{\mathrm{X}}$ & noun prefix of class $\mathrm{x}$ \\
$\mathrm{OM}_{\mathrm{X}}$ & object marker of class $\mathrm{x}$ \\
$\mathrm{PROG}$ & progressive \\
PRS & present \\
$\mathrm{SM}_{\mathrm{X}}$ & subject marker of class $\mathrm{x}$
\end{tabular}




\section{References}

Bastin, Yvonne. 1983. La finale verbale -ide et l'imbrication en bantou. Tervuren, Belgique: Musée royal de l'Afrique centrale.

Bastin, Yvonne. 1986. Les suffixes causatifs dans les langues bantoues. Africana Linguistica 10.56145 .

Bastin, Yvonne, André Coupez, Evariste Mumba \& Thilo C. Schadeberg (eds.). 2002. Bantu lexical reconstructions 3 / Reconstructions lexicales bantoues 3. Tervuren: Royal Museum for Central Africa, online database: http://www.metafro.be/blr.

Bussmann, Hadumod, Gregory Trauth \& Kerstin Kazzazi. 1996. Routledge dictionary of language and linguistics. London/New York: Routledge.

Cann, Ronnie \& Patricia Mabugu. 2007. Constructional Polysemy: The applicative construction in chiShona. Metalinguistica 19.221-245.

Creissels, Denis. 2006. Syntaxe générale, une introduction typologique. Paris: Lavoisier.

Crowley, Terry. 1992. An introduction to historical linguistics. Auckland, New York: Oxford University Press.

Daeleman, Jan. 1977. A comparison of some zone B languages in Bantu. Africana Linguistica 7.93-144.

Dammann, Ernst. 1959. Inversiva und repetitiva in Bantusprachen. Afrika und Ubersee 43.116-27.

Demuth, Katherine. 1998. Argument structure and the acquisition of Sesotho applicatives. Linguistics 36.781-806.

Devos, Maud. 2008. A Grammar of Makwe. München: Lincom Europa.

Dixon, Robert M. W. 2000. A typology of causatives: Form, syntax and meaning. In R.M.W. Dixon \& A.Y. Aikhenvald (eds.), Changing valency: Case studies in transitivity, 30-83. Cambridge: Cambridge University Press.

Ellington, John. 1977. Aspects of the Tiene language. Madison: University of Wisconsin. PhDthesis.

Fortune, G. 1955. An analytical grammar of Shona. London, Cape Town, New York: Longmans, Green and Co.

Geniušiene, Emma. 1987. The typology of reflexives. Berlin: Mouton de Gruyter.

Guthrie, Malcolm. 1971. Comparative Bantu: An introduction to the comparative linguistics and prehistory of the Bantu languages. Volume 2: Bantu prehistory, inventory and indexes. London: Gregg International.

Haspelmath, Martin. 1990. The grammaticization of passive morphology. Studies in Language 14.25-72.

Heine, Bernd \& Tania Kuteva. 2002. World lexicon of grammaticalization. New York: Cambridge University Press.

Hulstaert, Gustaaf. 1965. Grammaire du lomongo. Deuxieme partie, Morphologie. Tervuren: Musée royal de l'Afrique centrale.

Hyman, Larry M. 2004. How to become a Kwa verb. Journal of West African Languages 30.69-88.

Hyman, Larry M. 2010. Affixation by Place of Articulation: the case of Tiene. In Jan Wohlgemuth \& Michael Cysouw (eds.), Rara \& rarissima: Documenting the fringes of linguistic diversity, 145-84. Berlin: Mouton de Gruyter.

Hyman, Larry M. \& Sharon Inkelas. 1997. Emergent templates: The unusual case of Tiene. University of Maryland Working Papers in Linguistics 5.92-116.

Kazenin, Konstantin I. 2001. Verbal reflexives and the middle voice. In M. Haspelmath, E. Konig, W. Oesterreicher \& W. Raible (eds.), Language typology and language universals, Vol. 2, 916-27. New York: de Gruyter.

Kemmer, Suzanne. 1993. The middle voice. Amsterdam: Benjamins.

Kimenyi, Alexandre. 1988. Passives in Kinyarwanda. In M . Shibatani (ed.), Passive and voice, 355-386. Amsterdam, Philadelphia: Benjamins. 


\section{Koen Bostoen and Léon Mundeke}

Koni Muluwa, Joseph \& Koen Bostoen. 2011. Umlaut in Bantu B70/80 languages of the Kwilu (DRC): Where did the final vowel go? Paper presented at the 41st Colloquium on African Languages and Linguistics, Leiden, 29-31 Augst 2011.

Maho, Jouni Filip. 2003. A classification of the Bantu languages: An update of Guthrie's referential system. In D. Nurse \& G. Philippson (eds.), The Bantu languages, 639-651. London, New York: Routledge.

Meeussen, Achille Emiel. 1967. Bantu grammatical reconstructions. Africana Linguistica 3.79121.

Motingea, Mangulu. 2005. Leboale et lebaate: langues bantoues du plateau des Uélé, Afrique centrale Tokyo: Research Institute for Languages and Cultures of Asia and Africa (ILCAA), Tokyo University of Foreign Studies.

Mundeke, Léon. 2006. Eléments de phonologie et de morphologie de la langue mbuun (B.87): approche structuraliste. Lubumbashi: Université de Lubumbashi Mémoire de DES

Nzang-Bie, Yolande. 2008. La dérivation causative dans les langues bantu du groupe A70. Africana Linguistica 14.85-107.

Peterson, David A. 2007. Applicative constructions. Oxford: Oxford University Press.

Polinsky, Maria. 2008. Applicative constructions. In M. Haspelmath, M.S. Dryer, D. Gil \& B. Comrie (eds.), The world atlas of language structures online. Munich: Max Planck Digital Library, chapter 107. Available online at http://wals.info/feature/109.

Rottland, Franz. 1977. Reflexes of Proto-Bantu phonemes in Yanzi (B85). Africana Linguistica 7.375-96.

Schadeberg, Thilo C. 1990. A sketch of Umbundu. Köln: R. Köppe Verlag.

Schadeberg, Thilo C. 2003. Derivation. In D. Nurse \& G. Philippson (eds.), The Bantu languages, 71-89. London, New York: Routledge.

Shibatani, Masayoshi \& Prashant Pardeshi. 2002. The causative continuum. In M. Shibatani (ed.), The grammar of causation and interpersonal manipulation, 85-126. Amsterdam, Philadelphia, PA: Benjamins.

Simango, Ron Silvester. 1995. The syntax of Bantu double object constructions. Columbia: University of South Carolina PhD-thesis.

Trithart, Lee. 1983. The applied suffix and transitivity: A historical study in Bantu. Los Angeles: UCLA PhD-thesis.

Voisin-Nouguier, Sylvie. 2002. Relations entre fonctions sémantiques et fonctions syntaxiques en wolof. Lyon: Université Lumière Lyon2 thèse de doctorat.

Voisin-Nouguier, Sylvie. 2003. Un syncrétisme causatif/applicatif en wolof? In Patrick Sauzet \& Anne Zribi-Hertz (eds.), Typologie des langues d'Afrique \& universaux de la grammaire. Volume 2: Benue-Kwa Wolof, 185-203. Paris: L'Harmattan.

Wald, Benji. 1998. Issues in the North/South syntactic split of East Bantu. In Ian Maddieson \& Thomas J. Hinnebusch (eds.), Language history and linguistic description in Africa, 95-106. Trenton: Africa World Press. 